\title{
Rod Bipolar Cells in the Macaque Monkey Retina: Immunoreactivity and Connectivity
}

\author{
Ulrike Grünert and Paul R. Martin \\ Max-Planck-Institut für Hirnforschung, Deutschordenstrasse 46, W-6000 Frankfurt/M. 71, Germany
}

\begin{abstract}
Rod bipolar cells in the macaque monkey retina were labeled by three antibodies: an antibody against the $\alpha$ - and $\beta$-subspecies of protein kinase C (PKC), a polyclonal antiserum against the $L 7$ protein from mouse cerebellum, and a monoclonal antibody against rabbit olfactory bulb (MAb 115A10). The MAb $115 A 10$ antibody also labeled some cone bipolar and some amacrine cells.
\end{abstract}

The antibody against PKC was used to study the synaptic connectivity of rod bipolar cells. Reconstructions of 28 rod spherules showed that usually two and up to four rod bipolar processes invaginate each rod spherule. Six rod bipolar axons in the inner plexiform layer were reconstructed; they all showed the same pattern of connectivity. Synaptic output at rod bipolar dyads usually was onto two amacrine cell profiles: one that resembled the All amacrine cell and another that frequently made a reciprocal synapse. Rod bipolar cells did not contact ganglion cells. Synaptic input to rod bipolar cells came from reciprocal amacrine cells at dyads and other amacrine cells. In these respects, the rod pathway in the monkey is very similar to that described in cat and rabbit.

The density of rod bipolar cells was determined and compared with the density of rods. There is a maximum of 15,000$20,000 \mathrm{rod}$ bipolar cells $/ \mathrm{mm}^{2}$ at $1-3 \mathrm{~mm}$ eccentricity, close to where rod density is maximum. Rod density is 10 times higher than rod bipolar cell density within $2 \mathbf{~} \mathbf{m m}$ of the fovea, and $\mathbf{3 0}$ times higher at $\mathbf{1 5} \mathrm{mm}$ eccentricity. This change in relative density is compensated by an increase in the number of rods contacted by individual rod bipolar cells (seen in Golgi-stained whole-mount retina) so that the number of rod bipolar terminal boutons in each rod photoreceptor remains relatively constant with changing eccentricity. We estimate that each rod bipolar cell is contacted by about 20 rods at 2-4 $\mathrm{mm}$ eccentricity and about 60 rods at $6-7 \mathrm{~mm}$ eccentricity.

\footnotetext{
Received Jan. 4, 1991; revised Mar. 18, 1991; accepted Apr. 5, 1991.

We thank Heinz Wässle for encouragement, generous support, and helpful discussions throughout this project and for critically reading the manuscript. Thanks are also due to Brian B. Boycott for giving us access to his collection of Golgistained retinas and for critically reading and improving the English version of the manuscript. We are grateful to S. C. Fujita and J. I. Morgan for providing antibodies, to Barry B. Lee for supplying the monkey retinas, and to Christine Curcio for helpful comments on the manuscript. We also thank Barbara Tuschen and Walter Hofer for excellent technical assistance, Felicitas Boij and Edeltraut Thielen for help with illustrations, and Irmgard Odenthal for typing the manuscript.

Correspondence should be addressed to Ulrike Grünert, Max-Planck-Institut für Hirnforschung, Deutschordenstrasse 46, W-6000 Frankfurt/M. 71, Germany. Copyright (C) 1991 Society for Neuroscience $0270-6474 / 91 / 112742-17 \$ 03.00 / 0$
}

In the primate, as in other mammals, scotopic vision is mediated by rod photoreceptors, and photopic and color vision by cone photoreceptors. As Ramón y Cajal (1893) first recognized, rods and cones are contacted by distinct bipolar cell types. The synaptic connectivity of rod bipolar and cone bipolar cells has been well studied in cat and rabbit retina. In these species, it is well established that cone bipolar cells contact ganglion cells directly but rod bipolar cells do not. There are two pathways by which rod signals can reach the ganglion cells: by gap junctions between rod and cone photoreceptors (Raviola and Gilula, 1973; Kolb, 1977; Nelson, 1977; Smith et al., 1986) or via the rod bipolar cell and a narrow-field bistratified amacrine cell, the AII amacrine, which makes synapses with OFF- and ON-cone bipolar cells (for reviews, see Daw et al., 1990; Wässle et al., 1991). It is not yet known whether rod and cone signals in the primate follow the same lines.

There is converging evidence that a single type of rod bipolar cell exists in all mammalian retinas. First, all rod bipolar cells have a similar morphology, as has been well described from Golgi-impregnated retinas (Ramón y Cajal, 1893; Polyak, 1941; Boycott and Dowling, 1969; Boycott and Kolb, 1973). Second, the synaptic connections of rod bipolar cells in the inner plexiform layer (IPL) of the cat (Kolb and Famiglietti, 1974; Kolb, 1979; Kolb and Nelson, 1983; McGuire et al., 1984; Freed et al., 1987) and the rabbit (Raviola and Raviola, 1967; Raviola and Dacheux, 1987; Strettoi et al., 1990) appear to have the same general organization. Third, most physiological studies indicate that only one physiological type of rod bipolar cell exists that is depolarized upon light stimulation (Dacheux and Raviola, 1986; Müller et al., 1988; Daw et al., 1990; Wässle et al., 1991; but see also Nelson and Kolb, 1983).

Surprisingly little has been published on the rod pathway of the primate since the detailed description of the organization of the primate retina by Dowling and Boycott (1966). They found that, in the IPL of the parafoveal region, bipolar dyads contacting ganglion cell dendrites were more common than those contacting amacrine profiles only (see also Koontz and Hendrickson, 1987), possibly reflecting a high cone bipolar cell density in this region. However, the synaptic connectivity and distribution of rod bipolar cells in the primate retina have not been described in detail. In the outer plexiform layer (OPL), Missotten et al. (1963) found, in human rod spherules, two to seven rod bipolar dendrites. Linberg and Fisher (1988) reported only two rod bipolar dendrites per rod spherule. However, as these authors pointed out, in unlabeled material rod bipolar processes can easily be confused with projections of the rod spherule itself. The convergence of rods onto rod bipolar cells has been studied by Boycott and Dowling (1969), who estimated that each rod 
bipolar cell is contacted by $15-45$ rods; Kolb (1970) reconstructed a single Golgi-stained rod bipolar cell that contributed one dendrite to each of 33 rods.

Selective staining of rod bipolar cells using an antibody against the $\alpha$ - and $\beta$-subspecies of protein kinase C (PKC) from Amersham has been reported for several vertebrate species (Negishi et al., 1988; Greferath et al., 1990; Young and Vaney, 1990; Müller and Peich1, 1991). Onoda and Fujita (1987) and Onoda (1988) tested a monoclonal antibody against a homogenate of rabbit olfactory bulb (MAb 115A10) in a variety of vertebrate species and found that most bipolar cells were stained. Furthermore, a polyclonal antiserum (L7) raised against the L7 protein from mouse cerebellum (Oberdick et al., 1988) has been found to label rod bipolar cells in mouse and rabbit retinas (Berrebi et al., 1990; Oberdick et al., 1990).

In this study, we show by light and electron microscopy that rod bipolar cells in the macaque monkey retina are labeled by all three of these markers. With the MAb 115A10 antibody, some cone bipolar cells and some amacrine cells are also labeled. Using the PKC antibody, we have identified and counted rod bipolar cell dendritic processes in individual rod spherules and studied the synaptic connections of rod bipolar axons in the IPL. The quantitative distribution of rod bipolar cells in relation to that of rods was studied using the PKC and $\mathrm{L} 7$ antibodies.

A preliminary report of some of these results has been published previously (Grünert and Martin, 1990).

\section{Materials and Methods}

\section{Tissue preparation}

We studied 10 retinas from nine juvenile macaque monkeys, Macaca mulatta or $M$. fascularis, that were killed for experiments unrelated to those described here. Animals were given a lethal dose of pentobarbitone and perfused with physiological saline prior to perfusion with fixative for 10-15 min. For immunocytochemistry, the perfusion fixative contained $4 \%$ paraformaldehyde in phosphate buffer, $\mathrm{pH} 7.4$ (PB). When electron microscopy was to be used, $0.1 \%$ glutaraldehyde was added to the perfusate. The eyes were removed and opened by an encircling cut, the vitreous was dissected out, and the posterior eyecup was immersion fixed in $4 \%$ paraformaldehyde in $\mathrm{PB}$ for $2 \mathrm{hr}$ at $4^{\circ} \mathrm{C}$. After an overnight rinse in $\mathrm{PB}$ containing $0.01 \%$ sodium azide, the retina was removed from the sclera and carefully separated from the pigment epithelium.

In order to obtain optimally fixed material (for purposes of comparison), two retinas from two monkeys were immersion fixed in $2.5 \%$ glutaraldehyde and 1\% paraformaldehyde in PB for $2 \mathrm{hr}$. They were then dissected into small pieces $(1 \times 2 \mathrm{~mm})$ along the horizontal meridian from 0 to $6 \mathrm{~mm}$ cccentricity. The picces werc processed for routinc electron microscopy (EM) and embedded in Epon as described by Grünert and Wässle (1990).

For immunocytochemistry, the retina was sectioned either perpendicular to the vitreal surface (vertical sections) or parallel to it (horizontal sections). For vertical sections, small retinal pieces (squares of 3-4 mm) were cut out along the horizontal and vertical meridian and processed for either cryostat or vibratome sectioning. For cryostat sectioning, the pieces were immersed in $30 \%$ sucrose in PB overnight, frozen in embedding medium (Jung, Heidelberg), and then cut into 12-15- $\mu \mathrm{m}$-thick sections that were collected onto gelatin-coated slides. For vibratome sectioning, the pieces were embedded in agar, and 70- $\mu \mathrm{m}$-thick sections were cut. The vibratome sections were transferred into phosphate-buffered saline (PBS) and processed free-floating. Horizontal frozen sections, $70 \mu \mathrm{m}$ thick, were taken with a sliding microtome from largc pieces of retina that were dissected as described by Packer et al. (1989).

\section{Immunocytochemistry}

Antibodies. Mouse monoclonal antibody against PKC (PKC antibody) from bovine brain was purchased from Amersham (clone MC5; RPN.536). It recognizes the $\alpha$ - and $\beta$ - ( $\beta$ I and $\beta$ II) subspecies of PKC, but not the $\gamma$-form. Optimal staining was achieved using a dilution of $1: 50$ or $1: 100$.

The polyclonal antiserum against the $\mathrm{L} 7$ protein (L7 antiserum) was a kind gift of Dr. James I. Morgan (Roche Institute of Molecular Biology, Nutley, NJ). It was raised in rabbit against a synthetic peptide conjugate predicted from the $\mathrm{L} 7$ protein-coding sequence. The $\mathrm{L} 7$ protein was obtained from mouse brain, where it is only found in the cerebellum (for details, see Oberdick et al., 1988). By immunocytochemistry, it has been demonstrated that the $\mathrm{L} 7$ protein is localized to the cell bodies and processes of mouse Purkinje cells (Oberdick et al., 1988) and rod bipolar cells in mouse and rabbit (Berrebi et al., 1990). The L7 antiserum was used at a dilution of $1: 1000$ or $1: 2000$.

The monoclonal antibody MAb $115 \mathrm{~A} 10$ was generously provided by Dr. S. C. Fujita (Gunma University, Gunma, Japan). It was raised against a homogenate of the adult rabbit olfactory bulb (for details, see Mori et al., 1985) and is considered to stain most mammalian retinal bipolar cells (Onoda and Fujita, 1987; Onoda, 1988). Recently, we have shown that this antibody stains more bipolar cells than does the antibody against PKC in rabbit, rat, and cat retina (Greferath et al., 1990). The monoclonal antibody MAb $115 \mathrm{~A} 10$ was used at a dilution of $1: 100$ or 1:200.

In this article, we will use the terms "PKC labeled" and "L7 labeled" for cells that were immunoreactive to the corresponding antibodies, and the term "PKC-labeled sections" for sections that were processed with the antibody against PKC.

Tissue processing. Immunoreactivity was demonstrated using the avidin-biotin peroxidase complex (ABC) method according to Hsu et al. (1981) or the indirect immunofluorescence technique for double labeling. All cryostat and vibratome sections were processed as described in detail by Greferath et al. (1990). The $70-\mu \mathrm{m}$-thick horizontal sections were incubated with the antibodies as the other sections and then postfixed in 4\% paraformaldehyde in PB for $2 \mathrm{hr}$, rinsed in PB and distilled water, mounted onto gelatinized slides from $50 \%$ ethanol, left overnight in $95 \%$ ethanol and $5 \%$ formalin, dehydrated, and mounted in Permount.

For double labeling, vertical cryostat sections were incubated overnight in a mixture of one of the monoclonal antibodies, PKC or MAb $115 \mathrm{~A} 10$, respectively, and the $\mathrm{L} 7$ antiserum. The sections were then rinsed in three changes of $\mathrm{PB}$ and incubated for $1 \mathrm{hr}$ in a mixture of secondary antisera conjugated to fluorescent markers [fluorescein isothiocyanate (FITC) and tetramethyl rhodamine isothiocyanate (TRITC); Sigma]. Subsequently, the sections were rinsed in PB and coverslipped in glycerol. Cross-reactivity between the individual immunoreagents was tested by cross-fluorescence controls where sections were incubated with the two fluorescent markers only.

\section{Quantitative analysis}

Serial semithin (1-2 $\mu \mathrm{m})$ or ultrathin $(90-100 \mathrm{~nm})$ sections were taken horizontally or vertically from the flat-embedded vibratome sections. Every second semithin section was counterstained with toluidine blue. Ultrathin sections were stained with lead citrate for $2 \mathrm{~min}$.

Rod spherule reconstruction. Twenty-eight rod spherules were reconstructed from serial ultrathin sections cut horizontally from PKC-labeled vibratome sections and from unlabeled retinal pieces of known eccentricity. For each rod spherule, between 10 and 20 consecutive sections were analyzed by tracing the outlines of the spherules and the rod bipolar and horizontal cell processes onto acetate sheets.

The number of rods contacted by individual rod bipolar cells was estimated from two Golgi-stained whole-mounted retinas (from Boycott et al., 1987). Rod bipolar cells were identified by their dendritic and axonal morphology (Boycott and Dowling, 1969), and the number of terminal boutons in the OPL and outer nuclear layer (ONL) was counted for each cell. Eleven cells from eccentricities between 2 and $7 \mathrm{~mm}$ in the ventral retina were drawn under $2000 \times$ magnification using a camera lucida. Their dendritic field area was estimated by connecting the outermost dendritic terminals and measuring the area of the enclosed polygon.

Rod bipolar axon reconstruction. Two series of 100 ultrathin sections were cut vertically from two PKC-labeled vibratome sections. A total of six labeled axons and their axon terminals were chosen, and pictures of about 40 consecutive sections per axon were taken of the labeled processes in the inner plexiform layer. Negatives were printed at a final magnification of $20,000 \times$, and montages were assembled. Reconstructions were made by tracing the outlines of the axon onto acetate sheets 


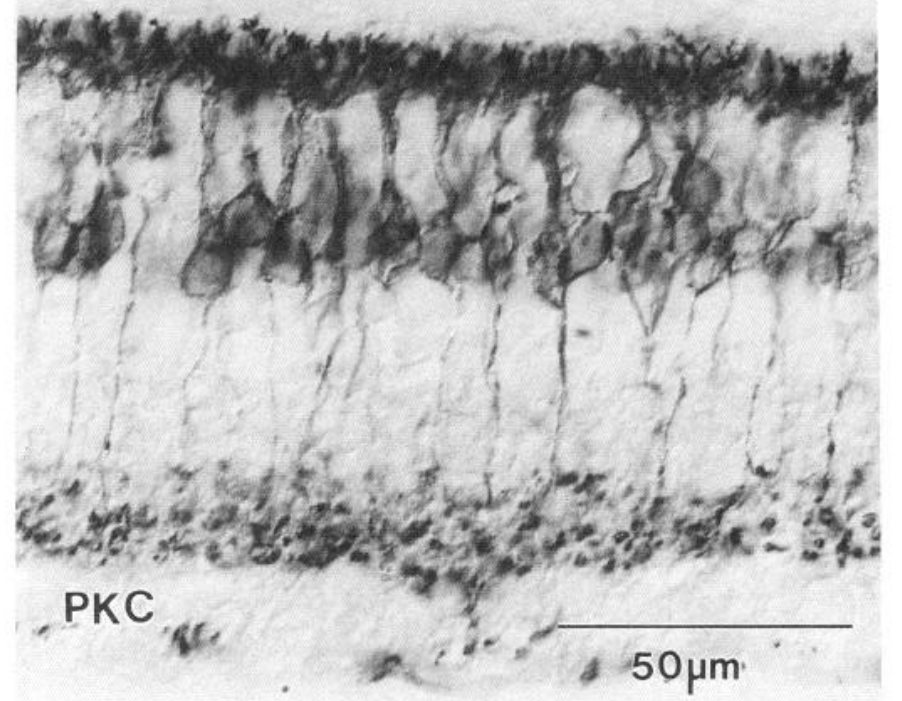

ONL
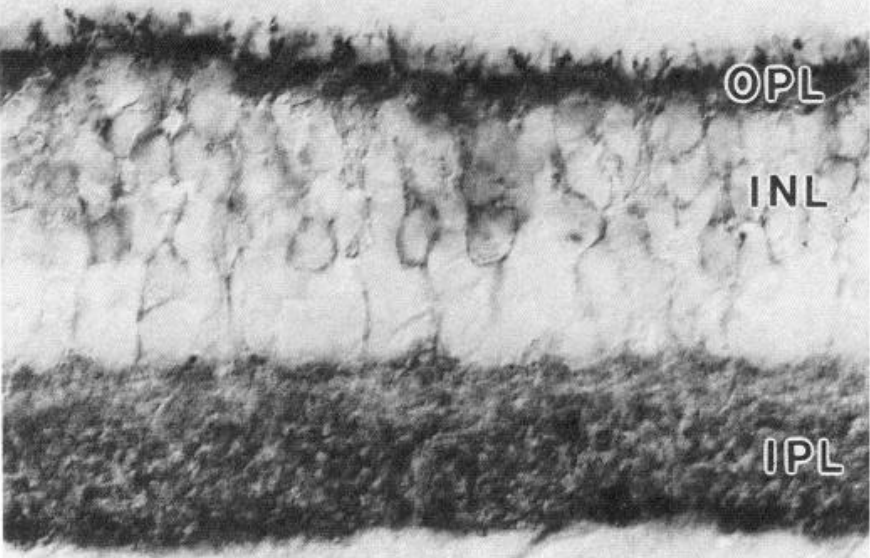

MAb

GCL
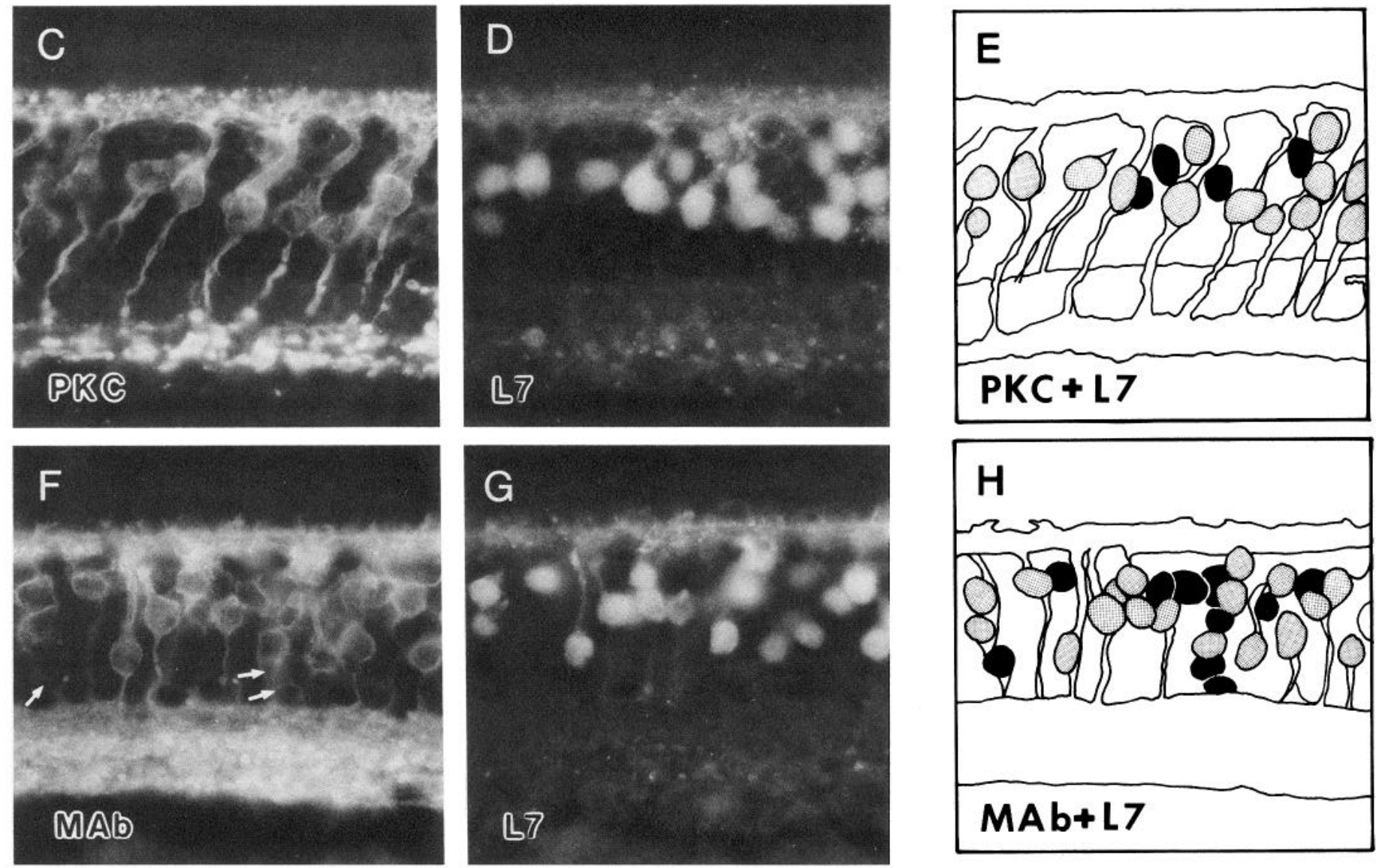
and then assembling the individual drawings. The localization of input and output synapses was determined using the criteria of Dowling and Boycott (1966). For a complete reconstruction, a series of about 40 sections or a range of about $4 \mu \mathrm{m}$ usually was necessary. Because the antibody did not penetrate more than $5 \mu \mathrm{m}$ into the vibratome section, and because ultrastructural preservation was poor close to its surface, most reconstructions remained incomplete. It was also difficult to attribute tiny labeled branches unequivocally to a distinct axon because all rod bipolar axons and all their axon terminals were labeled. Thus, we cannot exclude the possibility that the reconstructed axons had some fine side branches that we did not identify.

Density estimation. The density and distribution of PKC- and L7. labeled cells were estimated both from horizontal (tangential) $70-\mu \mathrm{m}$ sections and from semithin 1- or $2-\mu \mathrm{m}$ vertical (radial) sections. In horizontal sections, the density of labeled cells and the underlying photoreceptors could be compared directly, but in areas of high cell density, the labeled cells often obscured one another, and analysis was restricted to those areas of the retina where the section included the entire INL. In addition, antibody penetration in 70- $\mu \mathrm{m}$ sections (as in whole-mounted retinas) appeared to be hindered by the outer and inner limiting membranes. This was not a problem in the semithin vertical sections, which had the advantage that they could be lightly counterstained with Nissl dyes so that the density of other cell populations could be measured.

Measurements were made with the help of a semiautomated image measurement system (Halasz and Martin, 1984) similar to those described by others (Curcio et al., 1989; Wikler et al., 1990) but optimized for the reconstruction of cell density from cell profiles measured in vertical sections. Both the size and the position of cell profiles could be recorded, and cell density was calculated using the recursive reconstruction method of Rose and Rohrlich (1988). This enabled us to account for changes in cell size with eccentricity that otherwise bias the estimation of cell density from profile density. Density estimates obtained using this method from low-power electron micrographs or using the disector method on consecutive semithin sections (Sterio, 1984) gave results that agreed to within $10 \%$.

\section{Results}

\section{Morphology of immunoreactive cells}

The labeling patterns obtained with the three bipolar cell markers used in this study are shown in Figure 1 and summarized in Table 1. Rod bipolar cells were labeled by all three markers. The typical morphology of rod bipolar cells as seen in Golgi preparations (Polyak, 1941; Boycott and Dowling, 1969) was most obvious in the retina processed for PKC immunoreactivity (Fig. 1 $A, C$ ). The entire cell except for the nucleus was labeled. Sections that had been processed for L7 immunoreactivity showed labeled cells in the same region of the inner nuclear layer (INL) as those that had been processed for PKC immunoreactivity. The morphology of the cells labeled with the L7 antiserum was difficult to distinguish because predominantly the nucleus was immunoreactive and dendrites, axons, and axon terminals were only weakly labeled.

To establish whether the same cells were labeled with the two antibodies, we incubated sections with both L7 antiserum and
Table 1. Labeling pattern of the bipolar cell markers

\begin{tabular}{|c|c|c|c|c|}
\hline \multirow[b]{2}{*}{ Antibodies } & \multicolumn{4}{|l|}{ Cell types } \\
\hline & Rod bipolar & $\begin{array}{l}\text { Invagi- } \\
\text { nating } \\
\text { cone } \\
\text { bipolar }\end{array}$ & $\begin{array}{l}\text { Flat } \\
\text { bipolar }\end{array}$ & $\begin{array}{l}\text { Ama- } \\
\text { crine }\end{array}$ \\
\hline PKC & + (all) & - & - & $+($ rare $)$ \\
\hline L7 & + (all) & $?$ (possible) & - & - \\
\hline MAb $115 A 10$ & + (all) & + (some) & - & + (some) \\
\hline
\end{tabular}

the PKC antibody and visualized immunoreactivity by using different fluorescent secondary antibodies. Nearly all cells labeled with the PKC antibody were also labeled with the $\mathrm{L} 7$ antiserum (Fig. 1C-E). In the central retina, 86\% (119 of 139) of cells were double labeled, and $10 \%$ were labeled exclusively with the $\mathrm{L} 7$ antiserum. Only $4 \%$ were labeled only with the PKC antibody; these were all in the inner half of the INL and might have been amacrine cells (Negishi et al., 1988). Cells labeled exclusively with the L 7 antiserum were distributed evenly among the double-labeled cells. The L7 antiserum consistently produced a higher-contrast label than the PKC antibody. Thus, we cannot exclude the possibility that the density of cells labeled with the PKC antibody was slightly underestimated. Very occasionally, with the PKC antibody, we found labeled astrocytes and/or Müller cell terminals in the ganglion cell layer (GCL). These cell types were never stained with the $\mathrm{L} 7$ antiserum and were not further investigated in this study.

The third bipolar cell marker used in this study (MAb 115A10) clearly labeled other cell types in addition to rod bipolar cells (Fig. $1 B, F$ ). In the OPL, an intensely labeled plexus can be seen. In the INL, many labeled cells were seen in the middle to outer half, and some weaker-stained cells, presumably amacrine cells, were seen in the inner half. The entire IPL was labeled. The label was most intense in the region where the rod bipolar cells terminate, slightly less intense in the middle (ON-sublamina), and weakest in the OFF-sublamina. Double labeling using both the MAb 1.15A10 antibody and the L7 antiserum showed that all cells labeled with the $\mathrm{L} 7$ antiserum were also labeled with the monoclonal antibody (Fig. $1 F-H$ ). In the central retina, we found that, of a total of 289 labeled cells, 74\% were labeled with both antibodies. The remaining $26 \%$ were labeled with the MAb $115 \mathrm{~A} 10$ antibody exclusively. Most of the single-labeled cells $(78 \%)$ were found in the middle to outer half of the INL; the others $(22 \%)$ were located in the inner half of the INL. We conclude that, in addition to rod bipolar cells, the MAb $115 \mathrm{~A} 10$

\footnotetext{
$\leftarrow$

Figure 1. Micrographs of vertical cryostat sections labeled with different bipolar cell markers. The section in $A$ was processed for PKC-like immunoreactivity. Labeled cells have the morphology of rod bipolar cells. The cell soma is located in the middle to outer half of the INL, the dendrites branch in the OPL and extend to the ONL, and the axons terminate deep in the IPL close to the GCL. The section in $B$ was processed with the MAb 115A10 antibody. The OPL is heavily labeled, and labeled processes innervate rod spherules and cone pedicles. Cell somata are only weakly labeled, but in total, more cells are labeled than with the PKC antibody in $A$. Note also the intensely labeled IPL. IS, photoreceptor inner segments. $C$ and $D$ show a section incubated simultaneously with the PKC antibody (secondary antibody, FITC-conjugated) and the L7 antiserum (secondary antibody, TRITC-conjugated). $E$ shows a schematic drawing summarizing the double-label experiment shown in $C$ and $D$. Double-labeled cells are shaded; solid cells are those stained with the L7 antiserum only. $F$ and $G$ show a section simultaneously incubated with the MAb 115A10 antibody (secondary antibody, TRITC-conjugated) and the L7 antiserum (secondary antibody, FITC-conjugated). All cells but one that were labeled with the L7 antiserum were also labeled with the monoclonal antibody. More cells were labeled with the MAb $115 \mathrm{Al} 0$ antibody than with the $\mathrm{L} 7$ antiserum; some of them were amacrine cells (arrows in $F$ ). $H$ summarizes the double-label experiment shown in $F$ and $G$. Double-labeled cells are shaded; solid cells are those stained with the MAb 115A10 antibody only. One cell at the edge of the field (white) was labeled with the $\mathrm{L} 7$ antiserum only. Scale bar, $50 \mu \mathrm{m}$.
} 

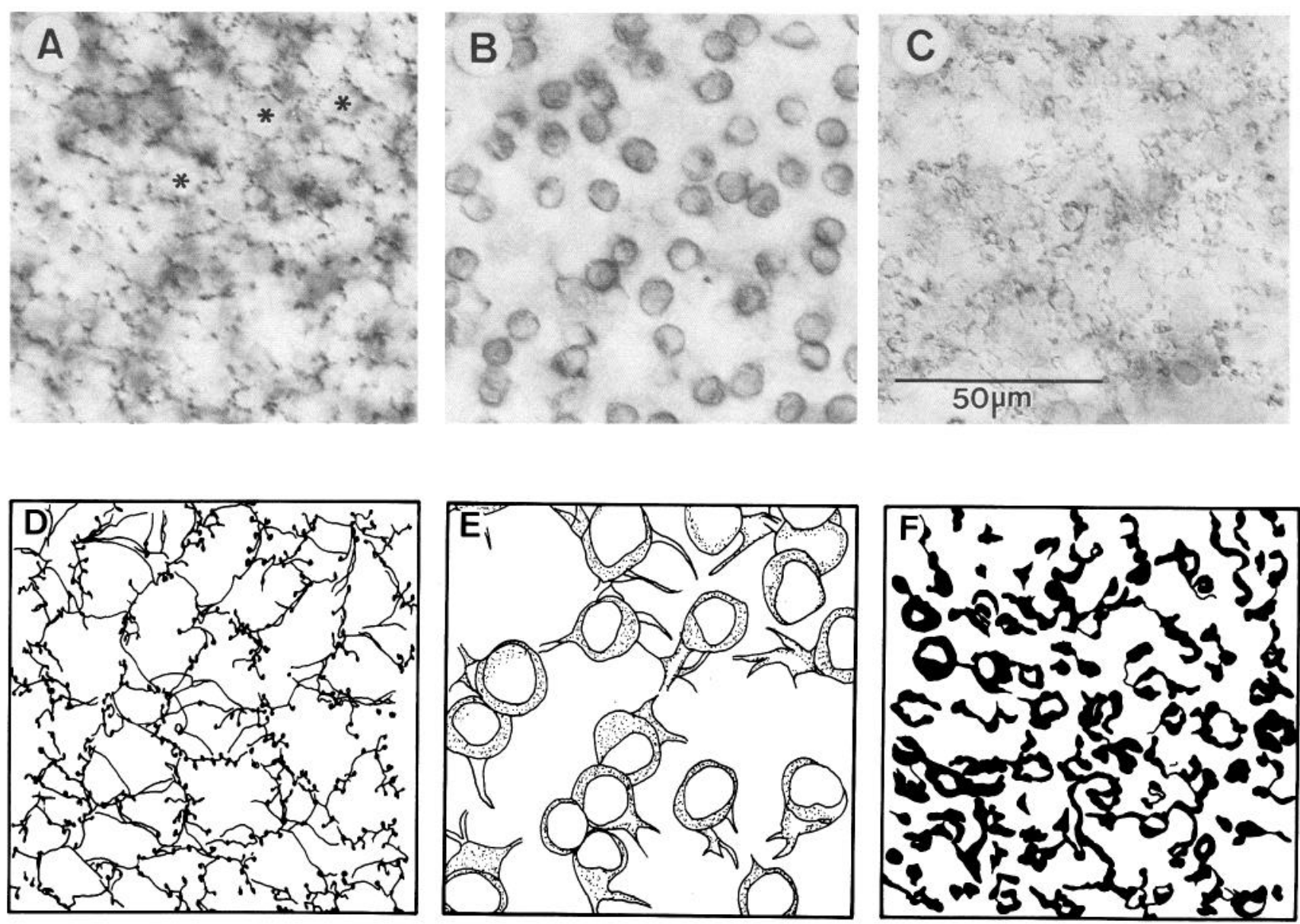

Figure 2. Micrographs and schematic drawings of PKC-labeled cells at $7 \mathrm{~mm}$ eccentricity taken at different planes of focus. $A$ and $D$ show the tips of labeled dendritic branchlets surrounding cone pedicles (asterisks in $A$ ). $B$ and $E$ show labeled cell bodies in the INL. $C$ and $F$ show labeled axon terminals close to the GCL. Unlabeled patches appear at the location of ganglion cell bodies. Scale bar in $C, 50 \mu \mathrm{m}$ for $A-C ; D-F$ are $50 \mu \mathrm{m}^{2}$.

antibody labels some cone bipolar cells (perhaps the invaginating type; see below) and some amacrine cells.

Figure 2 shows micrographs and schematic drawings of PKClabeled cells in a $70-\mu \mathrm{m}$ horizontal section taken at different focal planes. The focal plane in Figure 2, $A$ and $D$, cuts through the photoreceptor terminals and shows that labeled dendritic branchlets pass cone pedicles to innervate rod spherules. The focus in Figure 2, $B$ and $E$, is on the INL and shows labeled cell somata. Figure 2, $C$ and $F$, shows the border between IPL and GCL with labeled axon terminals.

\section{Outer plexiform layer: electron microscopy}

PKC immunoreactivity proved to be very sensitive to glutaraldehyde. Concentrations of glutaraldehyde in the primary fixative above $0.1 \%$ effectively abolished PKC immunoreactivity. The quality of ultrastructural preservation was thus not optimal, but good enough to study the synaptic connectivity of labeled cell processes (see below). Staining with $\mathrm{L} 7$ antiserum and MAb $115 \mathrm{~A} 10$ antibody was found to be inferior to PKC labeling.

All three bipolar cell markers labeled the invaginating central processes in rod spherules (Fig. $3 B-G$ ). With the PKC antibody, we very occasionally saw a weakly labeled process in the synaptic invagination of a cone pedicle. We could not trace these processes to their origin, but because we never saw labeled cone bipolar axon terminals in the IPL, we think that labeled processes in cone pedicles might originate from rod bipolar cells. A similar result has been reported by Dacheux and Raviola (1986) for a physiologically and morphologically identified rod bipolar cell in rabbit, where two out of 80-120 branchlets contacted cone pedicles.

Consistent with our light microscopical results, the MAb $115 \mathrm{~A} 10$ antibody labeled invaginating processes in both rod spherules and cone pedicles (Fig. 3G,H); flat bipolar contacts (Boycott and Dowling, 1969) were not labeled. In any given

Figure 3. Electron micrographs of photoreceptor terminals. $A-F$ show rod spherules $(R S)$. The central elements in the synaptic invagination are rod bipolar dendrites $(R B)$; the lateral elements are horizontal cell processes (arrows). Synaptic ribbons are indicated by arrowheads. The rod spherule in $A$ is from an unlabeled retina; that in $B$, from a retina processed for $\mathrm{L} 7$ immunoreactivity; and that in $C$, from a retina processed for PKC immunoreactivity. $D-F$ show rod spherules of a retina processed for PKC immunoreactivity. $D$ and $E$ are sections through the same rod spherule. Two labeled processes enter the synaptic invagination. $F$ shows a labeled rod bipolar dendrite that branches just before it enters two neighboring spherules. $G$ and $H$ show sections through cone pedicles $(C P)$ and rod spherules of a retina processed with the MAb $115 \mathrm{~A} 10$ antibody. 

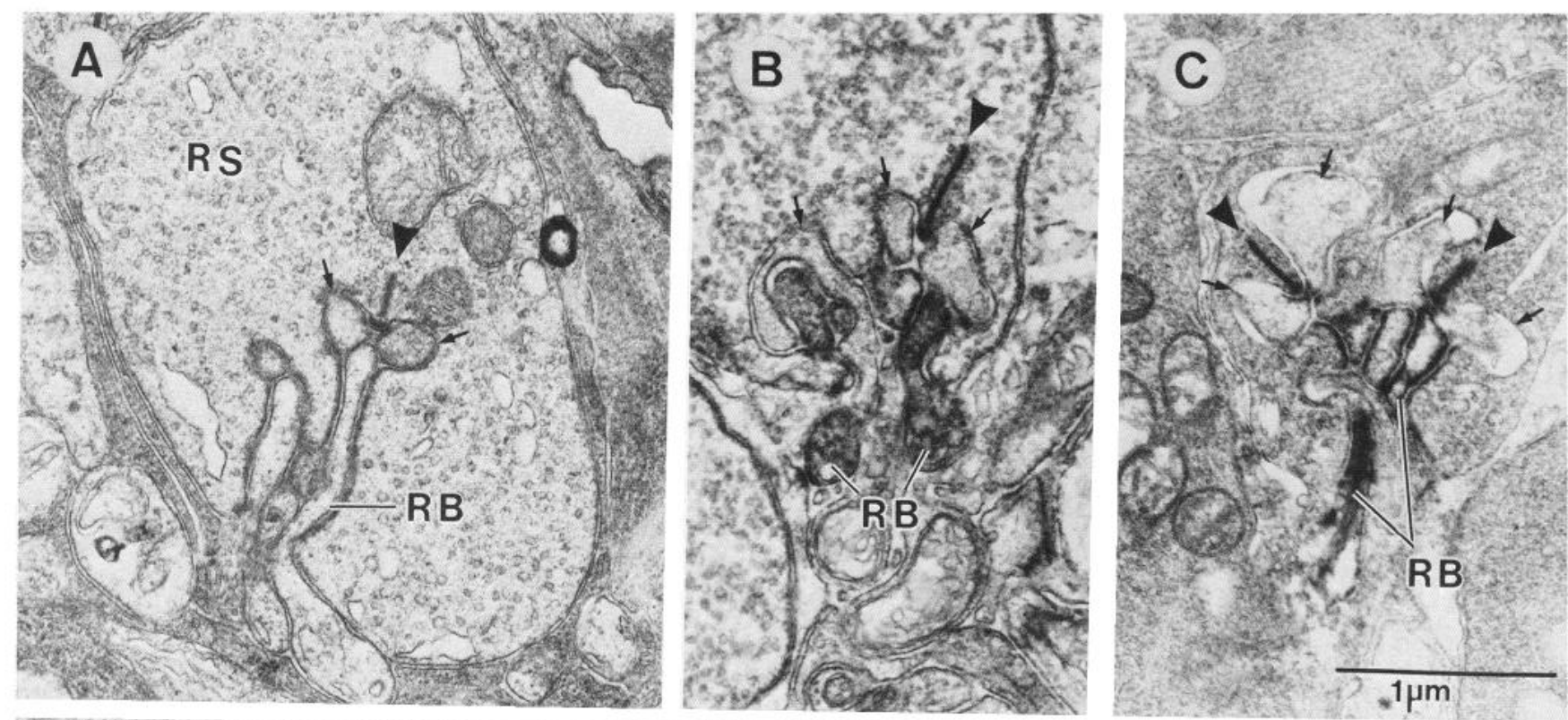
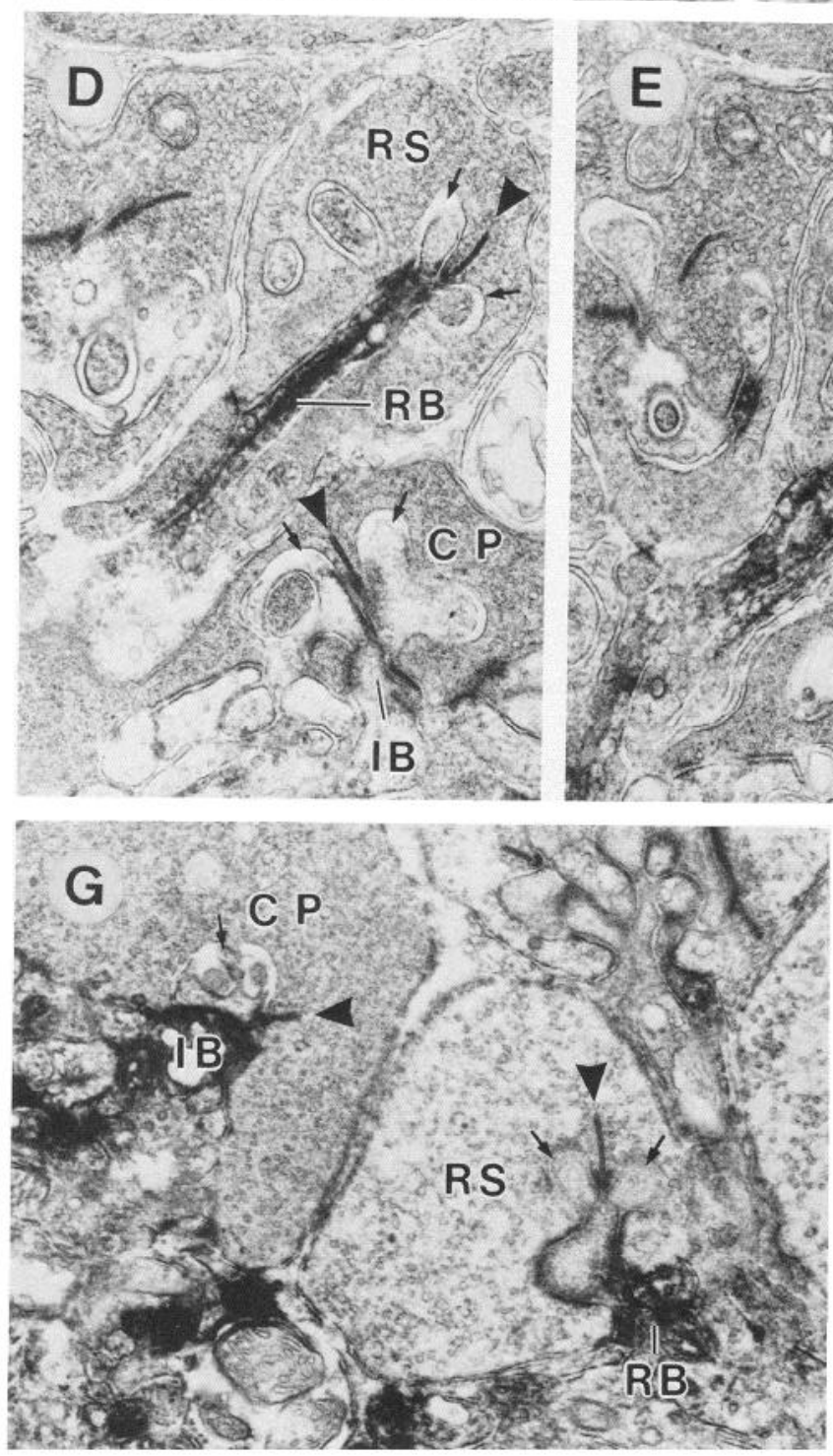
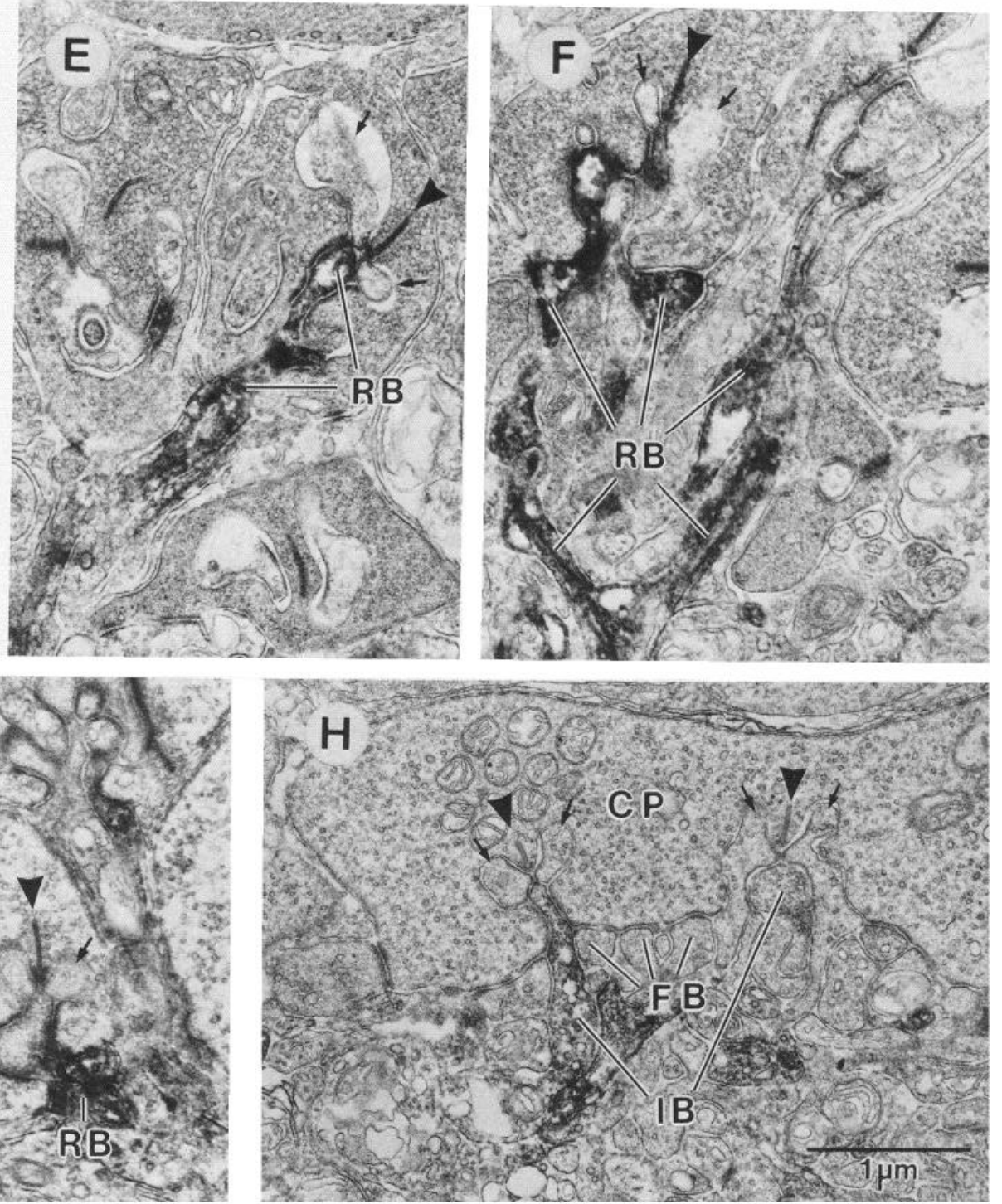

Labeled and unlabeled processes form the central elements in cone pedicles $(I B)$ and rod spherules $(R B)$. Processes of flat bipolar cells $(F B)$ are not labeled. Scale bars: $C, 1 \mu \mathrm{m}$ for $A-C ; H, 1 \mu \mathrm{m}$ for $D-H$. 

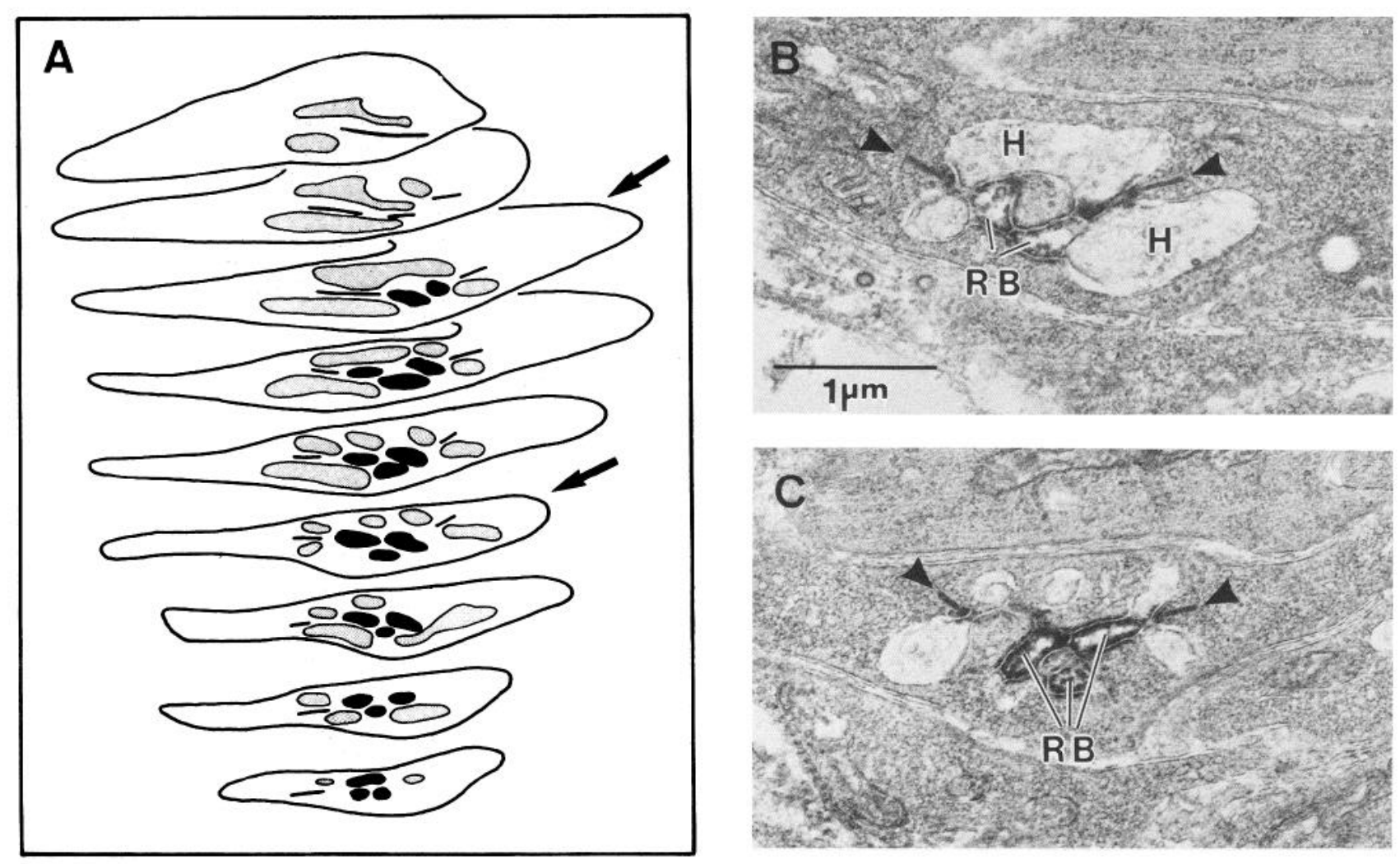

Figure 4. A, Schematic drawing of a rod spherule reconstructed from horizontal ultrathin sections. Every second section was drawn. The spherule is vertically oriented; the top of the diagram is close to the ONL. This rod spherule is invaginated by three rod bipolar branchlets (solid profiles) and three horizontal cell processes (shaded). The two synaptic ribbons are drawn as solid lines. $B$ and $C$ show (in mirror image) electron micrographs of two horizontal sections through the rod spherule reconstructed in $A$ (indicated by top and bottom arrows, respectively). Rod bipolar dendrites $(R B)$ show PKC immunoreactivity; horizontal cell processes $(H)$ are not labeled. The arrowheads indicate the synaptic ribbons. Scale bar, $1 \mu \mathrm{m}$.

cone pedicle, most but not all of the invaginating processes were labeled. We conclude that the MAb $115 \mathrm{~A} 10$ antibody labels at least one type of invaginating cone bipolar cell.

\section{Rod spherule reconstruction}

We have reconstructed (from PKC-stained material) 17 rod spherules from horizontal sections at 2-3 mm nasal to the fovea. At that eccentricity, they usually contained two labeled processes, one to two synaptic ribbons, and two horizontal cell processes (Table 2). The rod spherule reconstruction in Figure $4 A$ shows every other section traced from a series of electron micrographs, two of which are illustrated in Figure 4, $B$ and $C$. This rod spherule contained three labeled rod bipolar cell processes, three horizontal cell processes, and two synaptic ribbons. In none of the reconstructed rod spherules did we see unlabeled central elements, suggesting that all rod bipolar cells are labeled with the PKC antibody.

From an unstained, well-fixed retina, we have reconstructed 11 rod spherules at two other eccentricities (Fig. $3 A$ ). In central retina (at about $0.5 \mathrm{~mm}$ from the fovea), we reconstructed seven rod spherules. Each rod spherule contacted three or four rod bipolar cell processes (Table 2) and had two or three synaptic ribbons and three horizontal cell processes. In more peripheral retina (5-6 $\mathrm{mm}$ from the fovea), we reconstructed four rod spherules. They usually had two or three rod bipolar processes, two horizontal cell processes, and one synaptic ribbon (Table 2).

\section{Inner plexiform layer}

\section{Rod bipolar axons}

The distribution of PKC-labeled rod bipolar cell bodies and their axon terminals was measured in semithin sections. At 1$2 \mathrm{~mm}$ eccentricity, the majority of labeled cell bodies were located between $40 \%$ and $70 \%$ of the depth within the INL (Fig. 5). Axon terminals formed two bands within the IPL: one inner band was located at $80-105 \%$, and a narrower (outer) band was located at $45-60 \%$ (Fig. 5). The two bands were most obvious between 1 and $5 \mathrm{~mm}$ eccentricity. Each rod bipolar axon contributes to these two bands, as revealed by our $70-\mu \mathrm{m}$-thick horizontal sections and the EM analysis. For example, the rod bipolar axon shown in Figure $6 A$ thickens at about the middle of the IPL (outer band) and at the border with the GCL (inner band). Furthermore, in Golgi material (not illustrated), very fine branches originating from rod bipolar axons at about $60 \%$ of the depth of the IPL were frequently observed.

\section{Synaptic connections: qualitative aspects}

In unstained material, rod bipolar axon terminals (Fig. 6C) could be distinguished from cone bipolar axon terminals (Fig. $6 D$ ) by their synaptic output, but not by the darkness of the cytoplasm (which can serve as a distinguishing criterion in cat; Kolb and Famiglietti, 1974; Kolb, 1979; McGuire et al., 1984). Figure $6 B$ shows a PKC-labeled, and Figure $6 C$, an unlabeled, rod bipolar terminal. Each contains typical rod bipolar dyads. As in cat and rabbit, two amacrine cell processes were usually 


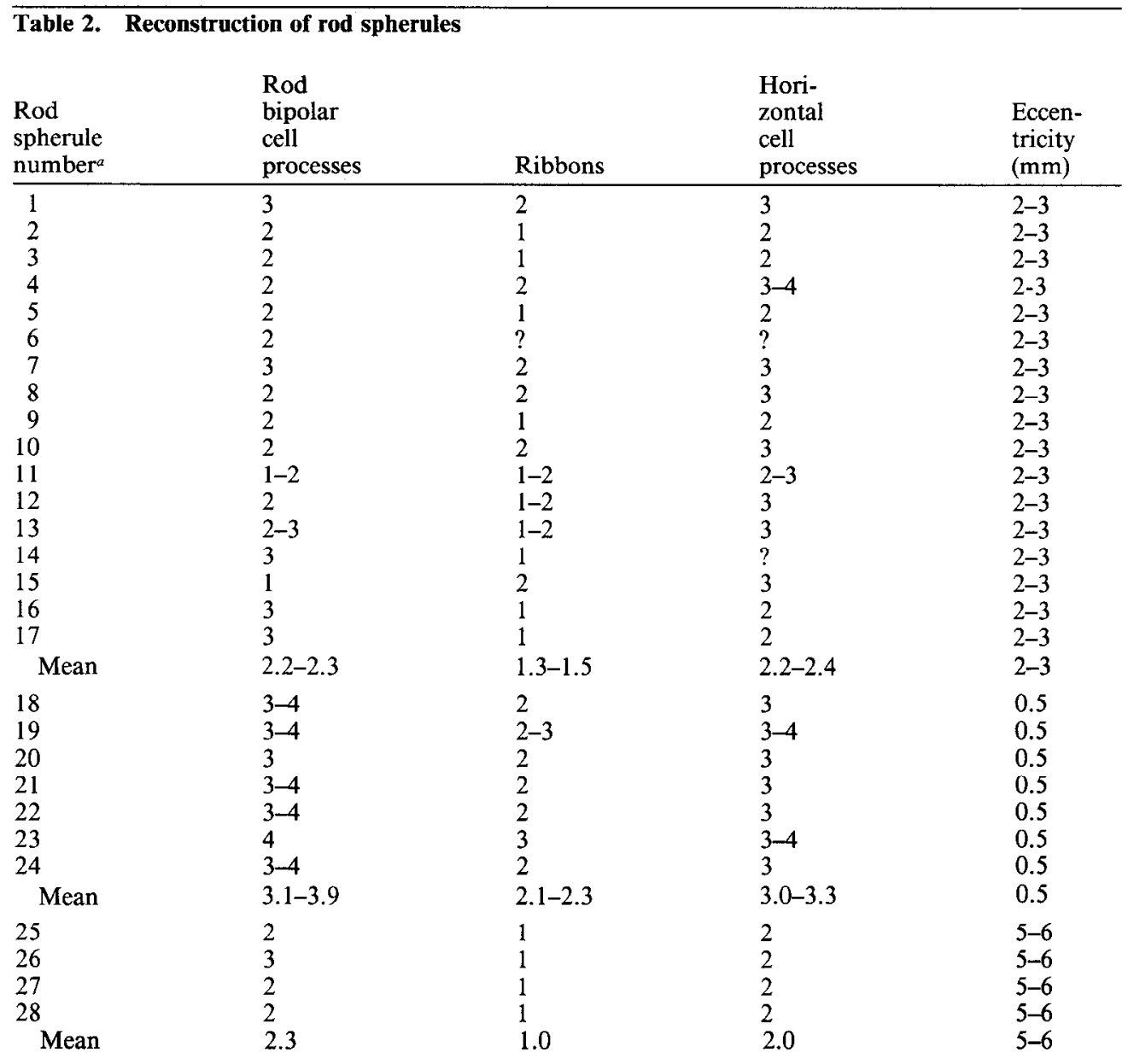

${ }^{a}$ Reconstructions of rod spherules 1-17 were from PKC-labeled material; those of 18-28 were from unlabeled material The number of rod bipolar cell processes, ribbons, and horizontal cell processes in each spherule is shown.

postsynaptic at each rod bipolar dyad. One process had a low number of synaptic vesicles, had more electron-dense cytoplasm, contained large mitochondria, and never made a reciprocal synapse. This is quite likely the dendrite of an AII amacrine cell (Famiglietti and Kolb, 1975; Kolb, 1979; Nelson, 1982). The other process was less electron dense, contained numerous synaptic vesicles, and sometimes made a reciprocal synapse onto the rod bipolar terminal. In our material processed for PKC immunoreactivity, only bipolar terminals that had this kind of synaptic arrangement were labeled. We did not unequivocally identify ganglion cells postsynaptic to rod bipolar dyads in the monkey, nor did we see axosomatic contacts, but we might occasionally have mistaken a ganglion cell dendrite for an amacrine profile, because some ganglion cell dendrites contained vesicle-like profiles. In the cat (McGuire et al., 1984; Freed and Sterling, 1988) and the rabbit retina (Raviola and Raviola, 1967; Strettoi et al., 1990), ganglion cell dendrites occasionally receive input from rod bipolar cells.

Synaptic input to labelcd axonal profiles came from reciprocal amacrine cells at dyads and from other conventional amacrine synapses (see Figs. $6 B, 8 F$ ). Consistent with the nomenclature used by Freed et al. (1987) and Strettoi et al. (1990), we will refer to the latter as "nonreciprocal" amacrine processes. However, it should be noted that other processes of the same cell could be postsynaptic at rod bipolar dyads. The amacrine cell types that made synaptic input onto rod bipolar cells were not identified in this study. However, the morphological appearance of amacrine profiles at the synapse was heterogeneous with respect to vesicle number, cytoplasmic contents, and shape of the synaptic junction, suggesting that synaptic input onto rod bipolar axons is made by more than one amacrine cell type.

\section{Synaptic connections: quantilative aspects}

The synaptic connections of rod bipolar terminals were studied in two ways: the synaptic connections of all rod bipolar profiles in one entire ultrathin section were analyzed, as were the synaptic connections of six reconstructed rod bipolar axons. The ultrathin section was from between 1 and $2 \mathrm{~mm}$ eccentricity (nasal retina) and contained 40 profiles of labeled cell bodies, corresponding to a cell density of 10,000 cells $/ \mathrm{mm}^{2}$, and about 60 labeled axonal profiles in the inner half of the IPL. Labeled axon terminals were arranged in two bands, as described above. All of them formed typical rod bipolar dyads.

Reconstructions of rod bipolar axons and their terminals were made from serial vertical ultrathin sections taken from nasal retina at 1-2 $\mathrm{mm}$ eccentricity. All axons showed the same general pattern of synaptic connectivity (Fig. 7, Table 3). The vast majority of output and input synapses were located in the inner half of the IPL, and there they were most frequent at the terminal swellings, only occasionally occurring along the axon. This is 


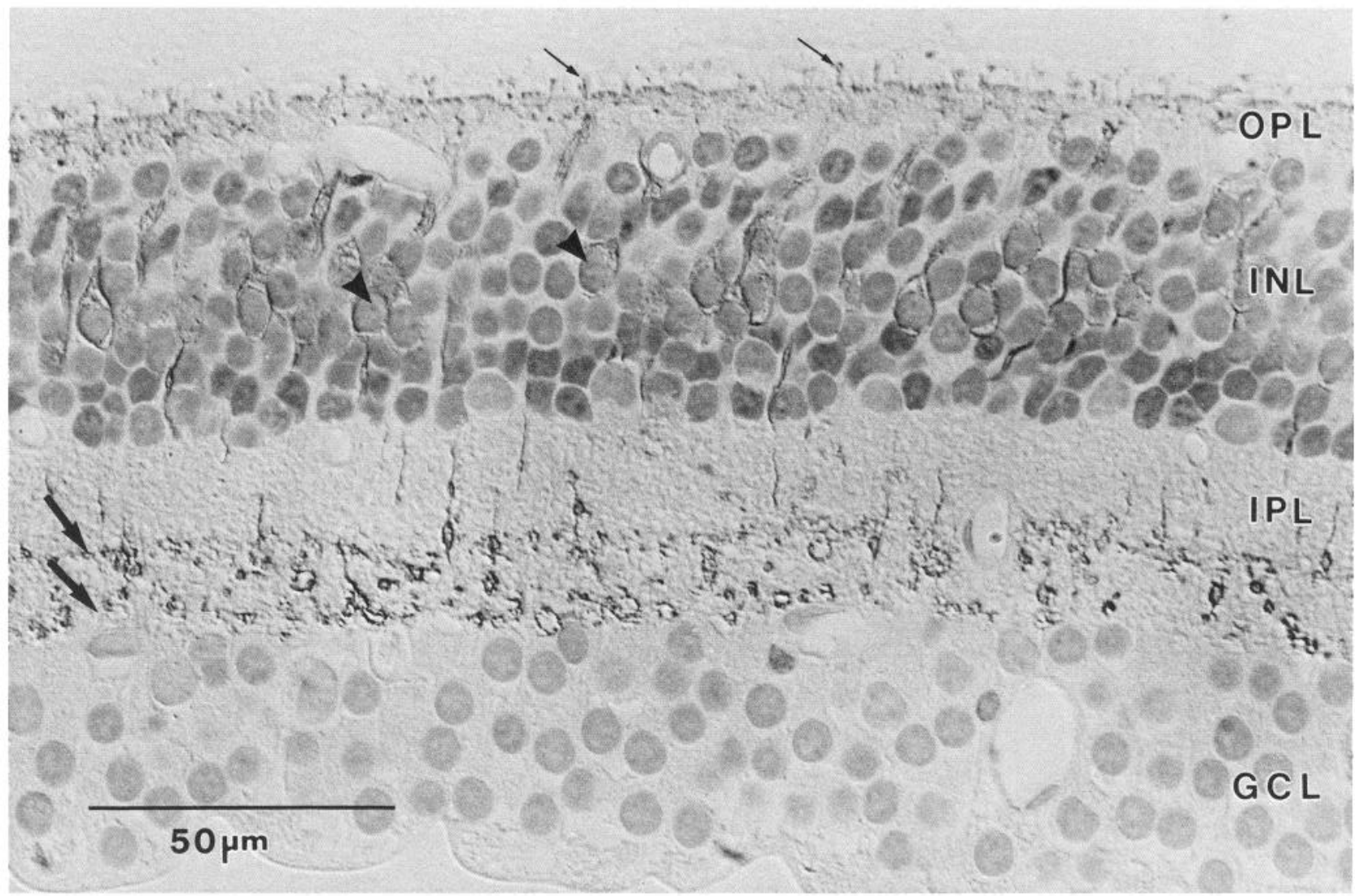

Figure 5. Micrograph of a semithin $(2-\mu \mathrm{m})$ section at about $1.5 \mathrm{~mm}$ eccentricity (temporal to the fovea) processed for PKC immunoreactivity and counterstained with toluidine blue. Labeled cells (arrowheads) are most frequent in the middle of the INL. Labeled axon terminals are most prominent in two bands of the IPL (large arrows). Labeled dendritic processes (small arrows) pass cone pedicles to innervate rod spherules. Scale bar, $50 \mu \mathrm{m}$.

consistent with findings in the cat and rabbit (McGuire et al., 1984; Freed et al., 1987; Strettoi et al., 1990). In the two almost completely reconstructed axons, 20 and 18 dyads, respectively, were found. This is lower than in cat rod bipolar cells, where up to 45 dyads (Kolb, 1979) or an average of 29 have been reported (McGuire et al., 1984). Strettoi et al. (1990) reported an average of 25 dyads in rabbit; this is closer to the value we obtained. However, our lower value might be caused by incomplete reconstructions, as discussed above.

About half ( 30 of 65$)$ of the "non-AII" amacrine profiles made reciprocal synapses at rod bipolar dyads. Such reciprocal synapses provided $23 \%$ ( 30 of 130 ) of the total amacrine input into rod bipolar cells (Table 3). This is considerably less than in cat, where a reciprocal component was found in all dyads and reciprocal input made up $70 \%$ of total input (McGuire et al., 1984). In rabbit, a reciprocal component was found in $83 \%$ of the dyads, and reciprocal input accounted for $47 \%$ of total input (Strettoi et al., 1990). In human retina, Marc and Liu (1985) found reciprocal components in $52 \%$ of the rod bipolar dyads, a number much closer to ours. Whether this difference between primate and other mammalian retinas reflects input from different sets of amacrine cells is not clear.

Occasionally, we saw rod bipolar axons that made synaptic contact in the outer half of the IPL (Fig. 7). They formed dyads onto pairs of amacrine profiles (Fig. $8 E$ ) and received nonreciprocal synaptic input from amacrine cell profiles (Fig. $8 A-C$ ). In the cat and rabbit, no synapses on rod bipolar axons have been described in the outer part of the IPL. In the cat, occasional nonreciprocal input synapses were seen at the border of sublamina a to sublamina b by McGuire et al. (1984) and Freed et al. (1987).

In many of the axon terminals investigated, the number of ribbons was higher than the number of dyads (Table 3); that is, not every ribbon was involved in a dyad, and these "nonsynaptic" ribbons appeared to be randomly distributed in the axonal endings, with no evidence of any synaptic specialization in adjacent sections (Fig. 8B-D). "Nonsynaptic" ribbons have also been seen in the rabbit (Raviola and Raviola, 1967), but not previously in man or monkey; their functional significance is as yet unknown.

Figure 6. Electron micrographs of vertical sections through the IPL. $A$ shows a presumed rod bipolar axon terminal $(R B)$ in an unlabeled retina. It makes output (arrowhead) and input (arrows) synapses with amacrine profiles in the inner half of the IPL. Borders with the INL and with the GCL are also shown. $B$ shows a rod bipolar axon terminal $(R B)$ in a retina processed for PKC immunoreactivity. Postsynaptic to the synaptic ribbons (arrowheads) are two amacrine $(A)$ cell processes, one of which is presumably that of an AII amacrine cell (AII). Synaptic input (arrows) 

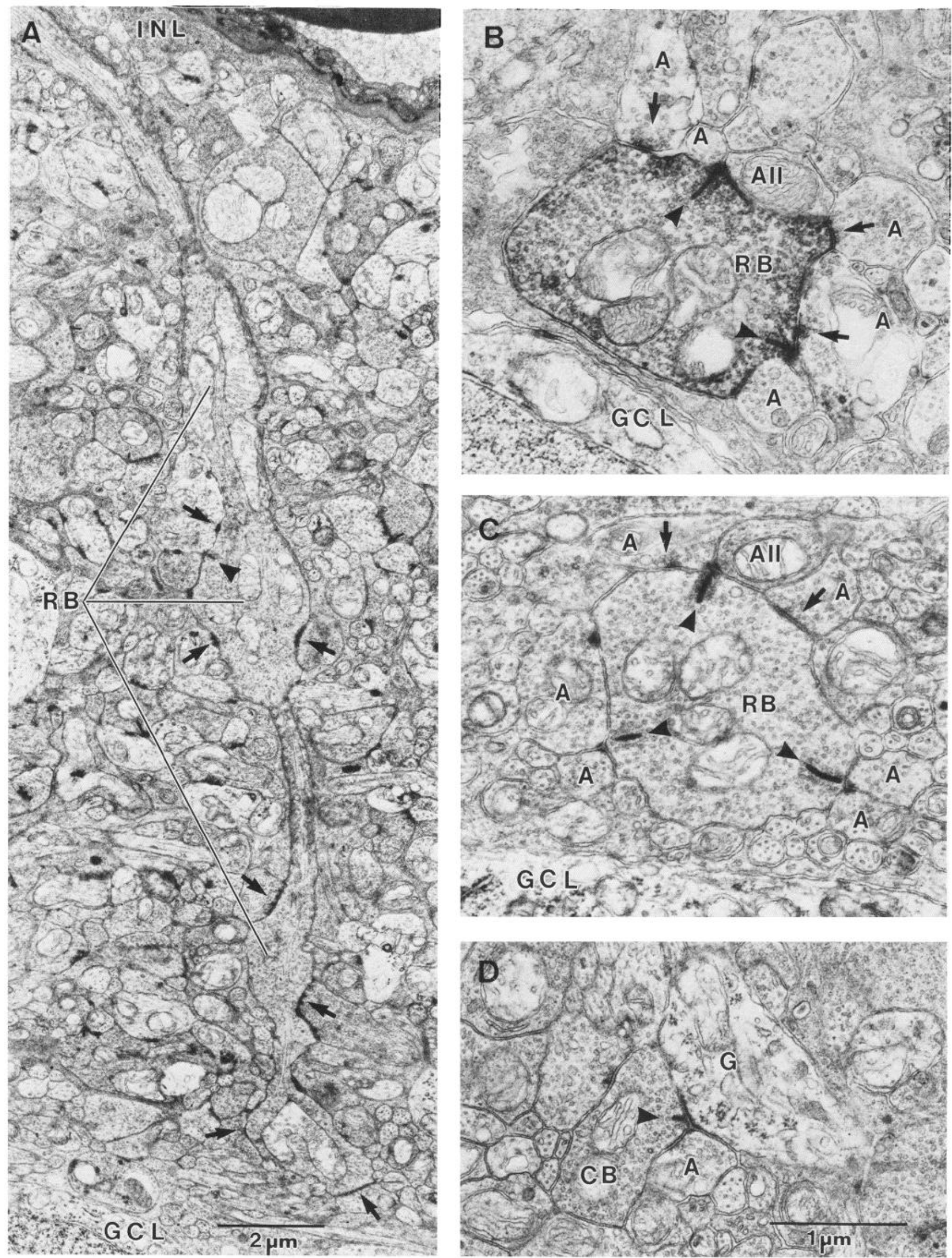

comes trom reciprocal and nonreciprocal amacrine profiles. $C$ shows a presumed rod bipolar $(R B)$, and $D$ shows a presumed cone bipolar $(C B)$ axon terminal in an unlabeled retina (same symbols and abbreviations as in $B$ ). $G$, ganglion cell dendrite. Scale bars: $A, 2 \mu \mathrm{m} ; D, 1 \mu \mathrm{m}$ for $B-D$. 

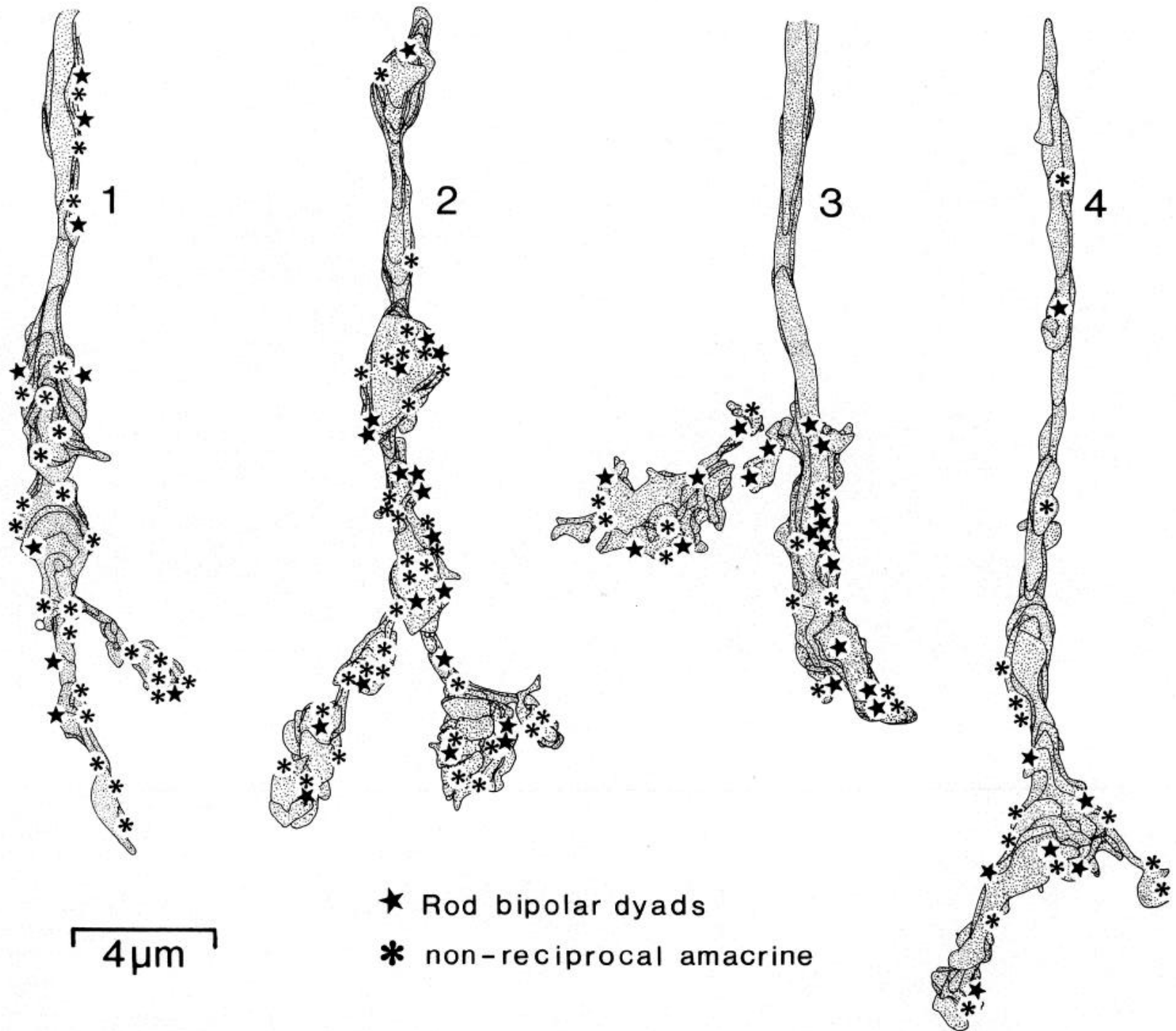

Figure 7. Schematic drawing of four rod bipolar axons reconstructed from serial sections of a PKC-labeled retina. Rod bipolar dyads are indicated by stars; nonreciprocal input synapses are indicated by asterisks.

\section{Distribution of rod bipolar cells}

The density and distribution of labeled cells were estimated both from horizontal $70-\mu$ m sections (Figs. 2, 9) and from semithin 1- or 2- $\mu \mathrm{m}$ vertical sections (Fig. 5). Both methods have certain advantages and disadvantages (see Materials and Methods), and we found that a reasonably accurate picture of the distribution of labeled cells depended on comparison of the results obtained from both methods.

The density of PKC-labeled cells rises rapidly from the perifovea to a peak between 1 and $3 \mathrm{~mm}$ from the fovea, then falls more gradually with increasing eccentricity. This can be seen in Figure $10 \mathrm{~A}-\mathrm{C}$ and was consistently observed. Figure $10 \mathrm{~A}$ compares the density of PKC-labeled cells (measured in $70-\mu \mathrm{m}$ horizontal sections) close to the dorsal and ventral retinal axis in one monkey. In ventral retina, the peak density of 17,000 cells/ $\mathrm{mm}^{2}$ was measured between 1 and $2 \mathrm{~mm}$. Labeled-cell density is slightly higher in dorsal retina. A peak density of 19,000 cells/ $\mathrm{mm}^{2}$ was measured close to $2 \mathrm{~mm}$ eccentricity; more central estimates could not be obtained from this retina. Figure $10 B$ shows the density of PKC- and L7-labeled cells in semithin vertical sections for 1-12 $\mathrm{mm}$ (PKC) and 7-12 $\mathrm{mm}$ (L7) along the ventral retinal axis of one monkey. In agreement with the results obtained from the double-labeling experiments, the density of cells labeled using the L7 antiserum was slightly higher than that of PKC-labeled cells. The distance between the curves could be accounted for if the L7 antiserum labeled 16\% more cells than the PKC antibody, but because this difference is within $1 \mathrm{SD}$ of the density estimate for either label, the value is without statistical significance.

\section{Central retina}

Figure 9 shows a PKC-labeled horizontal section through the fovea. Labeled cells are oriented so their dendrites are closer to the foveal center than are their axons. A few labeled cells are seen within the first $200 \mu \mathrm{m}$ of the fovea; these are less strongly oriented and have longer dendritic branches, presumably reflecting the paucity of rod spherules there.

From two retinas, we obtained semithin sections that ran 

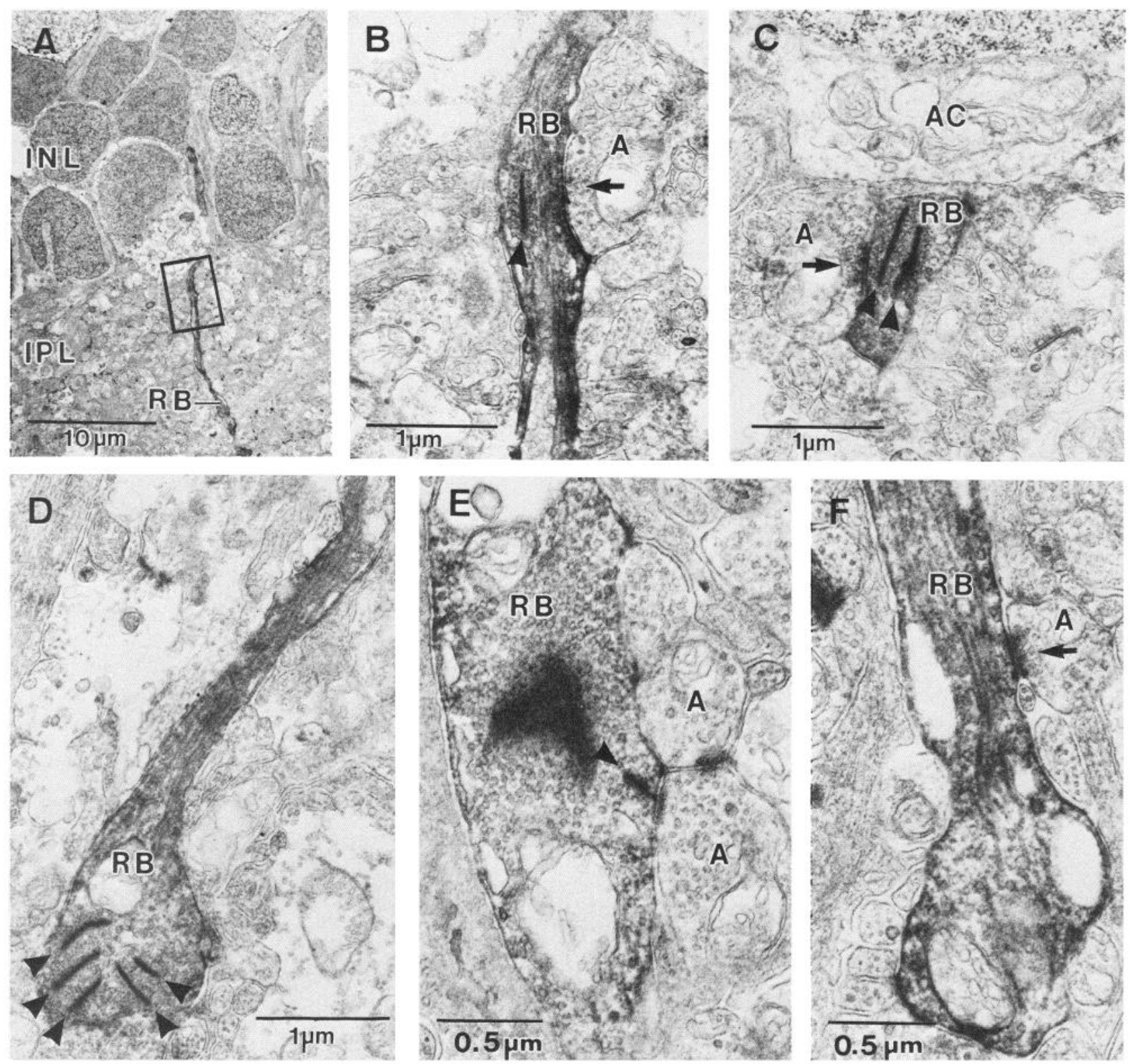

Figure 8. Electron micrographs of a retina processed for PKC immunoreactivity showing labeled rod bipolar axons (RB) in the IPL. $A$, A labeled rod bipolar axon descending from the INL into the IPL. The boxed area indicates the area shown at higher magnification in $B$. $B$ and $C$, Input synapses (arrows) onto a rod bipolar axon and ribbons (arrowheads) in the outer half of the IPL. $A C$, amacrine cell soma; $A$, amacrine cell profile. $D$, Rod bipolar axon terminal with five ribbons (arrowheads) that are not involved with dyads. $E$, Rod bipolar dyad, located in the outer half of the IPL. Postsynaptic to the ribbon (arrowhead) are two amacrine cell profiles $(A) . F$, Rod bipolar axon receiving nonreciprocal input from an amacrine cell profile (arrow).

Table 3. Synaptic connections of rod bipolar axon terminals

\begin{tabular}{|c|c|c|c|c|c|}
\hline \multirow{2}{*}{$\begin{array}{l}\text { Axon } \\
\text { termi- } \\
\text { nal } \\
\text { number }\end{array}$} & \multirow[b]{2}{*}{$\begin{array}{l}\text { Eccen- } \\
\text { tricity } \\
(\mathrm{mm})^{a}\end{array}$} & \multicolumn{2}{|c|}{ Output } & \multicolumn{2}{|l|}{ Input } \\
\hline & & Dyads & $\begin{array}{l}\text { Nonsyn- } \\
\text { aptic } \\
\text { ribbons }\end{array}$ & Reciprocal & $\begin{array}{l}\text { Non- } \\
\text { reciprocal }\end{array}$ \\
\hline $\begin{array}{l}1 \\
2 \\
3 \\
4 \\
5 \\
6\end{array}$ & $\begin{array}{l}1 \\
1 \\
2 \\
2 \\
2 \\
1\end{array}$ & $\begin{array}{l}9 \\
20 \\
18 \\
7 \\
2 \\
9\end{array}$ & $\begin{array}{l}5 \\
0 \\
5 \\
7 \\
5 \\
5\end{array}$ & $\begin{array}{l}3 \\
10 \\
8 \\
3 \\
2 \\
4\end{array}$ & $\begin{array}{l}25 \\
32 \\
12 \\
13 \\
9 \\
9\end{array}$ \\
\hline Total & & 65 & 27 & 30 & 100 \\
\hline
\end{tabular}




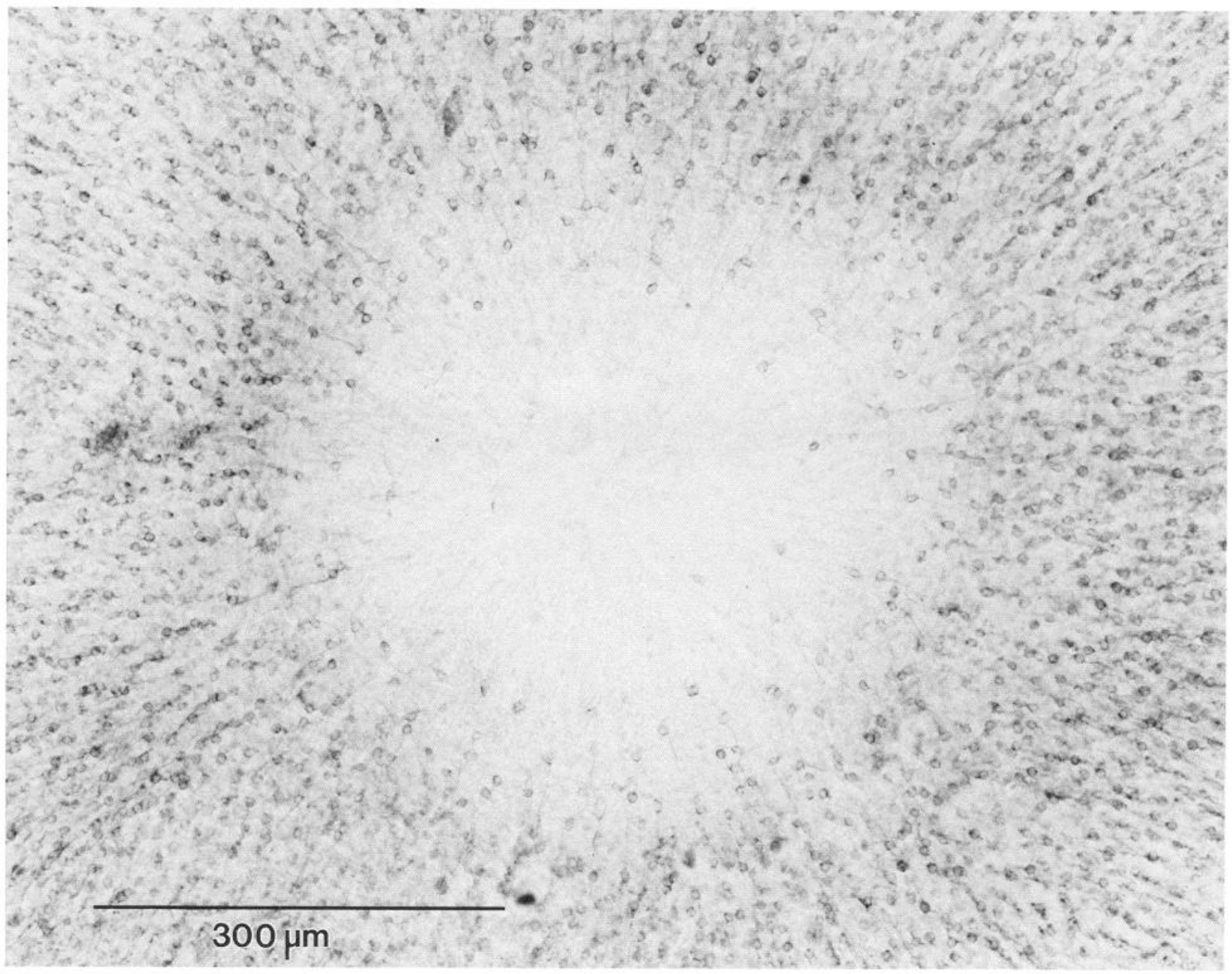

Figure 9. Micrograph of a 70- $\mu \mathrm{m}$ horizontal section through the fovea of the monkey retina processed for PKC immunoreactivity. The first labeled cells appear about $200 \mu \mathrm{m}$ from the center of the fovea. Scale bar, $300 \mu \mathrm{m}$.

directly through the center of the fovea along the temporal retinal axis, making accurate counts of foveal ganglion and rod bipolar cells possible. Figure $10 D$ shows data from one of these retinas. The first labeled cells appear about $200 \mu \mathrm{m}$ from the foveal center, and their density rises steeply to a maximum between 1.5 and $2 \mathrm{~mm}$ from the fovea. The maximum ganglion cell density in this retina is close to $800 \mu$ m eccentricity. Ganglion cell density drops more rapidly than that of labeled cells, so that rod bipolar cell density exceeds ganglion cell density at eccentricities above $3 \mathrm{~mm}$.

\section{Convergence of rods onto rod bipolar cells}

We determined the ratio of rod photoreceptors to rod bipolar cells by measuring the density of both rods and PKC-labeled cells in $70-\mu \mathrm{m}$ horizontal sections (Fig. 10C). This was only possible at a limited number of points (mostly in ventral retina) where the section included the entire INL as well as rod and cone inner segments. For this reason, we also compared our PKC-labeled cell density data with the average photoreceptor density curves given for pigtail macaque by Packer et al. (1989). This comparison is also shown in Figure $10 C$. No consistent difference in the ratio of rods to rod bipolar cells between dorsal and ventral retina was seen, suggesting that the higher rod den- sity in dorsal retina is accompanied by an increase in rod bipolar density. The ratio increased monotonically from a minimum of 5 within the first $2 \mathrm{~mm}$ of the fovea to over 20 at $10 \mathrm{~mm}$. At $15 \mathrm{~mm}$ (not shown), the ratio was close to 30 . From horizontal sections, we saw no obvious rod bipolar cell "hot spot" that could correspond to the localized rod photoreceptor density maximum in dorsal retina (Packer et al., 1989; Wikler et al., 1990); however, because our choice of sample locations was limited, it is possible that such a "hot spot" exists but we did not find it.

We can compare the number of terminal boutons seen on individual Golgi-stained rod bipolar cells with the ratio of rods to rod bipolar cells to obtain an estimate of the coverage factor for rod bipolar cells, that is, the number of rod bipolar cells that are contacted by a given rod spherule. Table 4 shows data obtained from 11 Golgi-stained rod bipolar cells that were located at different eccentricities (2-3 mm, $n=2 ; 3-4 \mathrm{~mm}, n=4 ; 6-7$ $\mathrm{mm}, n=3$ ) in the ventral retinal quadrant. Some of these cells are illustrated in Figure 11; similar values were obtained for cells at equivalent eccentricities in other retinal quadrants. With increasing eccentricity, the density of rod bipolar cells drops more rapidly than the density of rods (Fig. 10C). This change in relative density is balanced by an increase in the number of 
A

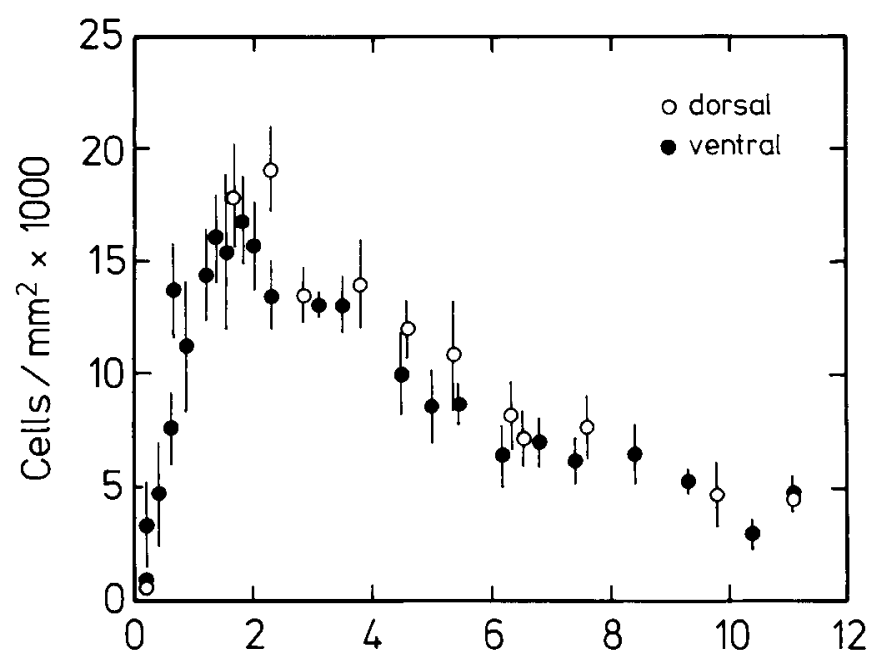

C

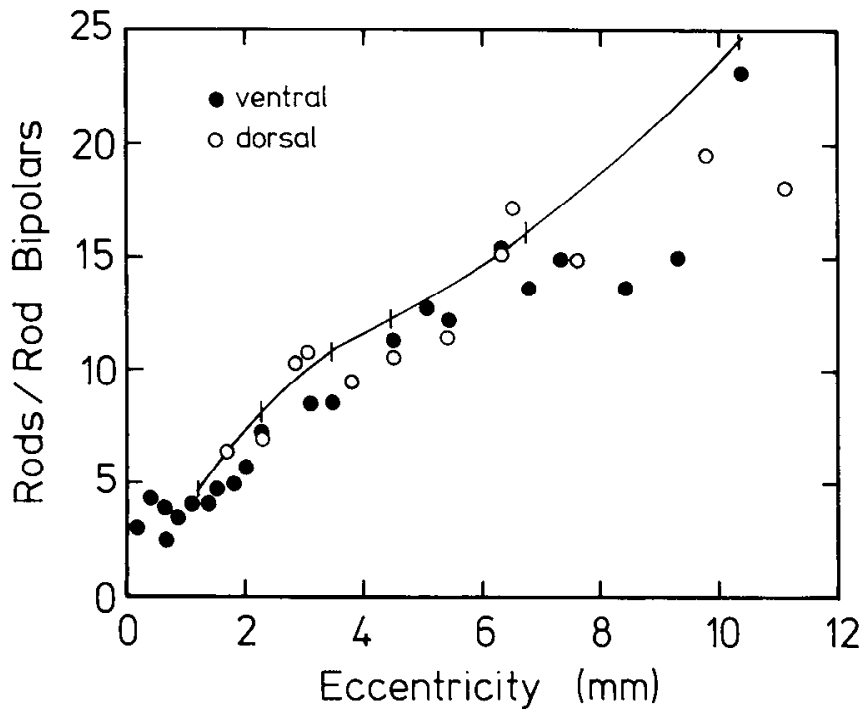

B

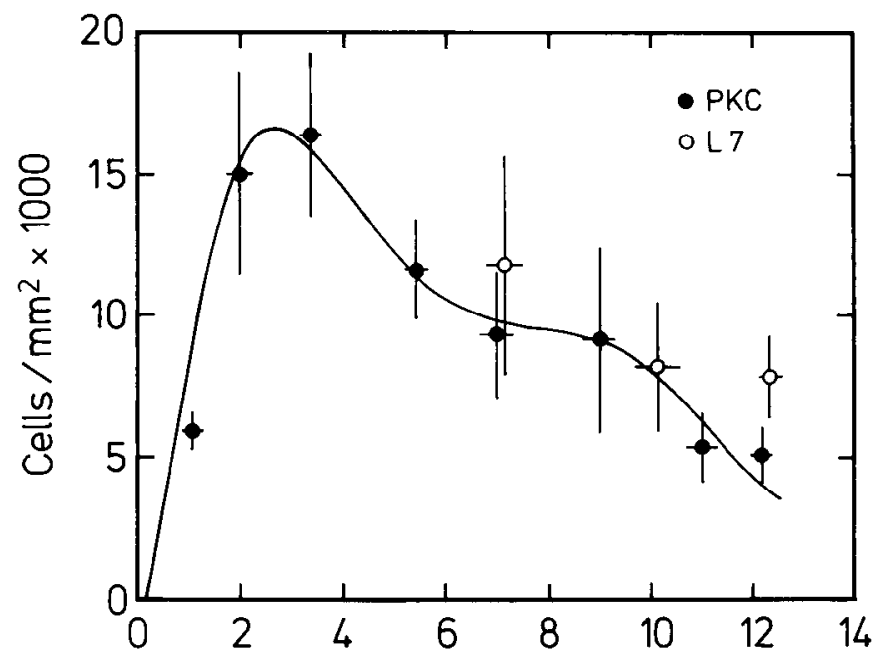

D

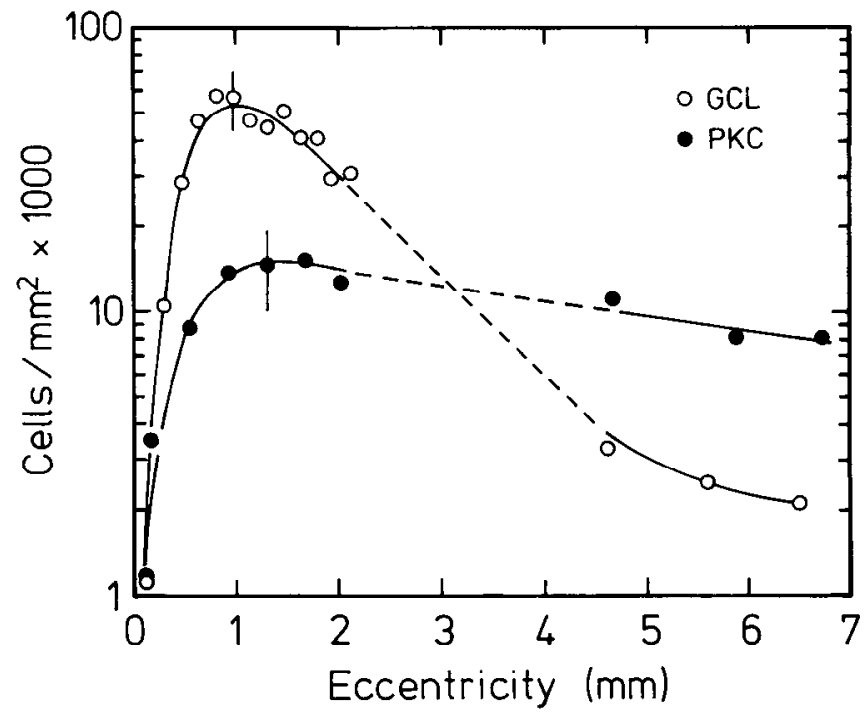

Figure 10. Distribution and convergence of rod bipolar cells. $A$, Density of PKC-immunoreactive cells along the dorsal and ventral axes of one retina. Each point shows the mean and SD of five samples. $B$, Density of PKC- and L7-immunoreactive cells along the ventral axis of one retina. The horizontal error bars show the horizontal (eccentricity) SD; the vertical error bars show the density SD. The curve is drawn from a polynomial interpolation of the PKC density data. $C$, Numerical convergence of rods onto rod bipolar cells. The ratio of photoreceptor density to PKC-labeled cell density for the dorsal and ventral axes of one retina is shown. The curve connects points (vertical dashes) where rod and rod bipolar cell densities were measured in the same retina. The open and solid circles compare rod bipolar densities with the average rod density estimates of Packer et al. (1989). $D$ compares the density of PKC-labeled cells with cells in the GCL for the temporal axis of one retina. Each point shows the mean of five GCL or 10 PKC samples. Data from two eccentricity ranges (0-2 and 4-7 mm) are shown. The broken lines are linear interpolations between the data sets. Retinal conversion: 1 degree $=200 \mu \mathrm{m}$. Data were corrected for shrinkage (linear factor, 0.9 ; areal factor, 0.81 ).

rods that converge onto each rod bipolar cell. The calculated coverage thus remains constant, with two to four rod bipolar terminal boutons in each rod. This result is in agreement with our EM reconstruction of rod spherules (Table 2), assuming that each bipolar cell dendrite in a rod spherule belongs to a different rod bipolar cell (Kolb, 1970). Table 4 also shows the potential rod-rod bipolar cell divergence ("coverage factor," Wässle and Riemann, 1978), that is, the maximum number of rod bipolar cells that can reach a given rod spherule. This is higher than the calculated coverage for eccentricities below $4 \mathrm{~mm}$, presumably because more of the potential receptive field of rod bipolar cells is taken up by cone pedicles in central retina.

\section{Discussion}

\section{Immunoreactivity of rod bipolar cells}

In this article, we have confirmed for the primate retina that the antibody against PKC labels rod bipolar cells. We have also compared the staining pattern obtained with the PKC antibody with that of two other bipolar cell markers: the L7 antiserum, which has been suggested to label rod bipolar cells (Berrebi et al., 1990; Oberdick et al., 1990), and the MAb 115A10 antibody, which has been suggested to label most bipolar cells (Onoda, 1988; Greferath et al., 1990). The double-labeling experiments show that the PKC antibody and the L7 antiserum label almost 


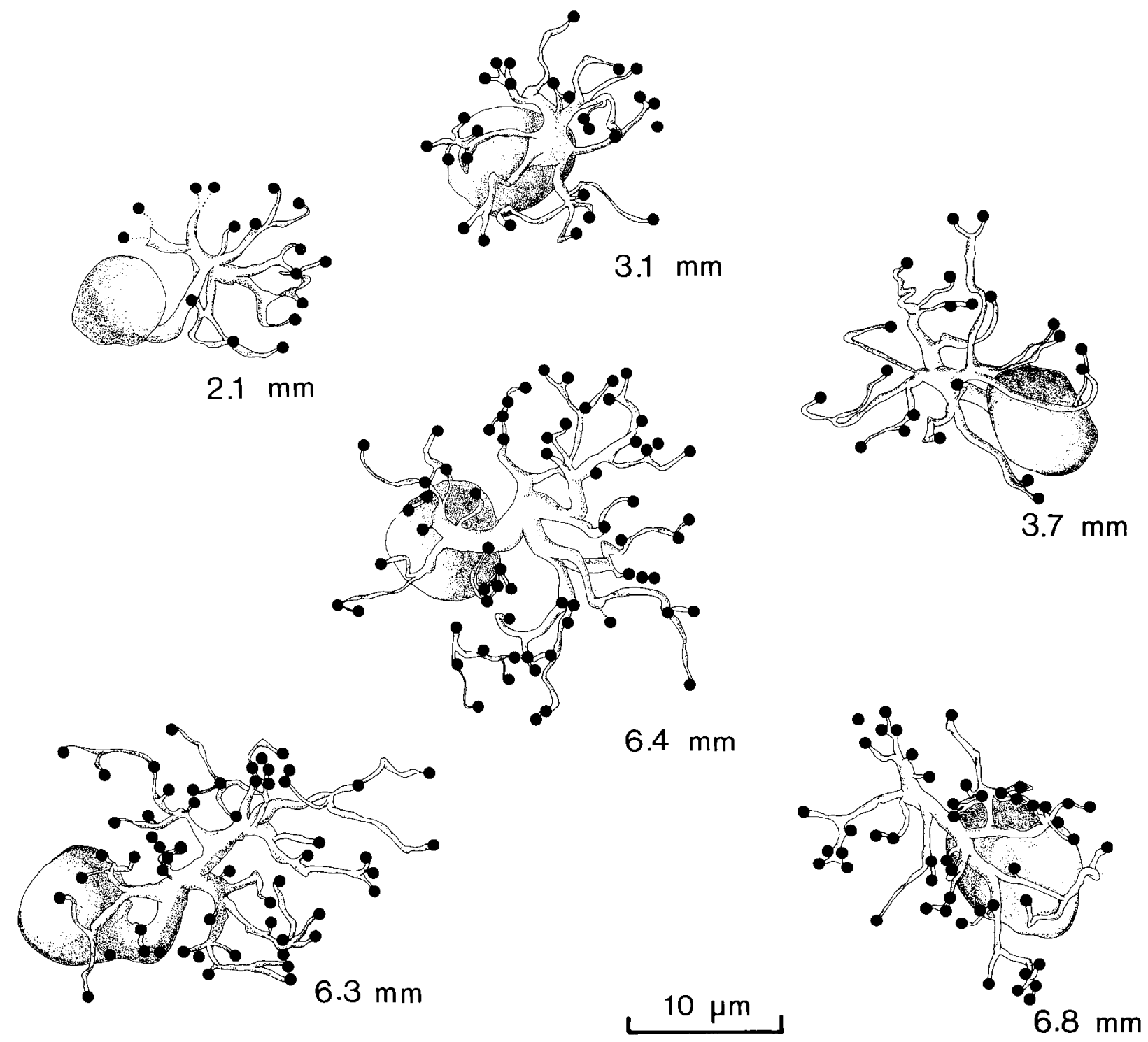

Figure 11. Golgi-stained rod bipolar cells drawn from monkey retinal whole-mounts. Only the soma and dendritic tree for each cell are shown. The solid circles show the position of terminal boutons. The distance (in $\mathrm{mm}$ ) from the fovea is shown below each cell; they were all in the ventral retinal quadrant. These distances are corrected for shrinkage (linear factor, 0.8); the drawings are not.

identical cell populations and that additional cells are labeled with the MAb 115 A10 antibody. The EM results provide conclusive evidence that all three markers label rod bipolar cells, and that the MAb 115A10 antibody additionally labels at least one type of invaginating cone bipolar cell. The latter antibody thus has potential as a marker for distinguishing $\mathrm{ON}$ - and OFFbipolar cells.

\section{Synaptic connections of rod hipolar cells}

Our study reveals that the synaptic connections of rod bipolar axons in the macaque monkey are, in general, very similar to those in cat and rabbit. Only one type of rod bipolar cell exists and is contacted by rods exclusively. On average, two rod bipolar dendrites originating from two different cells form the central elements in a rod spherule. In the IPL, rod bipolar axons terminate in the inner half, close to the GCL. They do not contact ganglion cells directly. Their synaptic output is at dyads onto two amacrine cell profiles, one of which most likely is an AII amacrine cell. In cat and primate, the AII amacrine cell has been shown to contain the inhibitory transmitter glycine (Marc and Liu, 1985; Pourcho and Goebel, 1985, 1987; Hendrickson et al., 1988), indicating further similarities in the rod pathway.

The second member at the rod bipolar dyad makes a reciprocal synapse onto the rod bipolar axon in half of the dyads we identified. We did not identify the amacrine cell types making these profiles. Recent investigations suggest that the reciprocal amacrine cell in the primate contains the inhibitory transmitter GABA (Grünert and Wässle, 1990; Koontz and Hendrickson, 1990). In the cat, four reciprocal amacrine cell types (A6, A8, A13, A 17) have been identified at rod bipolar dyads (Kolb and Nelson, 1983; Nelson and Kolb, 1985); most of them are thought to contain GABA (Freed et al., 1983, 1987; Pourcho and Goebel, 1983; Chun and Wässle, 1989). In the rabbit, two types of indoleamine-accumulating amacrine cells are postsynaptic at rod bipolar dyads: type 1 of the indoleamine-accumulating cells corresponds to the A17 (Raviola and Dacheux, 1987; Sandell 
Table 4. Convergence of rods onto rod bipolar cells

\section{Boutons/cell}

Rod bipolar cell density (cells $\left./ \mathrm{mm}^{2}\right)$

Bouton density (boutons $/ \mathrm{mm}^{2}$ )

Rod density (cells $/ \mathrm{mm}^{2}$ )

Divergence

Average diameter $(\mu \mathrm{m})$

Average area $\left(\mathrm{mm}^{2}\right)$

Potential divergence

\begin{tabular}{lcc} 
Eccentricity $(\mathrm{mm})$ & \\
\hline $2-3$ & $3-4$ & $6-7$ \\
15 & 22 & 56 \\
$1.5 \times 10^{4}$ & $1.4 \times 10^{4}$ & $0.7 \times 10^{4}$ \\
$2.25 \times 10^{5}$ & $3.08 \times 10^{5}$ & $3.92 \times 10^{5}$ \\
$1.2 \times 10^{5}$ & $1.4 \times 10^{5}$ & $1.2 \times 10^{5}$ \\
1.9 & 2.2 & 3.2 \\
15 & 18 & 24 \\
$1.8 \times 10^{-4}$ & $2.5 \times 10^{-4}$ & $4.5 \times 10^{-4}$ \\
2.7 & 3.5 & 3.2
\end{tabular}

Estimates of rod-rod bipolar cell convergence and divergence. The average number of terminal boutons on individual rod bipolar cells is multiplied by rod bipolar cell density to give the density of rod bipolar terminal boutons. This value divided by the density of rod photoreceptors gives the actual rod to rod bipolar cell divergence, assuming that each rod bipolar cell contributes only one terminal bouton to a given spherule. The average diameter and average area of the dendritic field of Golgi-stained RB cells are also shown. The area multiplied by red bipolar cell density gives the potential divergence, or the maximum number of bipolar cells that can reach a given rod spherule. et al., 1989); type 2 has not yet been identified (Strettoi et al., 1990). Indoleamine-accumulating amacrine cells in rabbit are thought to be GABAergic (Vaney, 1990). In summary, the second member at the rod bipolar dyad presumably uses GABA as a transmitter in various mammalian species.

Other putative GABAergic amacrine cells make nonreciprocal synapses onto the rod bipolar axon of the cat (Freed et al., 1987; Chun and Wässle, 1989). In the monkey, we found a significant number of nonreciprocal amacrine profiles that were presynaptic to rod bipolar axons. Because GABA-like immunoreactivity has been shown for many amacrine-to-bipolar synapses of the macaque monkey (Grünert and Wässle, 1990; Koontz and Hendrickson, 1990), it is possible that in the monkey, too, these profiles contain GABA.

Despite the remarkable similarity of the rod pathways in cat, rabbit, and monkey, there appear to be some quantitative differences. These concern primarily the amount of amacrine cell input onto rod bipolar cells and the number of amacrine cell types that are postsynaptic at dyad synapses (Strettoi et al., 1990). Whether these differences have physiological consequences is not known. The great similarity in fine structure and connectivity of the rod bipolar cell in the macaque monkey with that in other mammals suggests that it may have the same physiological properties (reviewed by Wässle et al., 1991).

\section{Convergence and divergence in the rod pathway}

The maximum density of 15,000-20,000 rod bipolar cells $/ \mathrm{mm}^{2}$ occurs $1-3 \mathrm{~mm}$ from the fovea, that is, close or slightly central to the rod density maximum. We can compare our 3-mm-eccentricity data with values from the cat near $2 \mathrm{~mm}$ eccentricity, where the highest rod (Steinberg et al., 1973) and rod bipolar cell (Greferath et al., 1990) densities occur. The density of both rods and rod bipolar cells is higher in the cat, and each rod bipolar cell is contacted by fewer rods, so the rod-rod bipolar cell divergence is similar in the cat $(<2$; Freed et al., 1987; Sterling et al., 1988) and monkey (1.9-2.2; see Table 4). Our results show that this divergence stays relatively constant with changing eccentricity between 2 and $6 \mathrm{~mm}$. This valuc could represent a limit on the number of rod bipolar terminal boutons that can be effectively driven by transmitter release from a single rod spherule, or it could (as suggested by Freed et al., 1987) reflect a need for rod bipolar cells to maintain a good signal-tonoise ratio by summing the signals from a limited number of rods.
The data from Golgi-stained rod bipolar cells and the calculations based on the rod-rod bipolar cell ratio suggest that, between 2 and $4 \mathrm{~mm}$, each rod bipolar cell is contacted by 1520 rods. This value is at the low end of the range reported by Boycott and Dowling (1969). Although our sample is small, the values are internally consistent with our reconstructions of rod spherules (which provide a similar divergence value; $c f$. Tables 2, 4).

Although our study does not address the question of whether scotopic rod signals are primarily transmitted to the ganglion cells via the rod bipolar cell or via the gap junctions between rods and cones, our data are consistent with psychophysical evidence for the former hypothesis. For rod vision, there is a minimum area of retina that is adapted by a small bleaching light. Cicerone and Hayhoe (1990) estimated that, for rod vision at $5^{\circ}$ eccentricity, even the smallest possible adapting stimulus will affect an area of human retina that would correspond to a $16-25-\mu \mathrm{m}$ diameter on the monkey retina. They proposed that the diameter of the rod bipolar cell's dendritic field could be an anatomical substrate of this phenomenon, and the rod bipolar cell diameters we measured (at slightly greater eccentricity) are close to the low end of this range. Our measurements predict that such an effect should be eccentricity dependent, because the average diameter of rod bipolar cell dendritic fields shows a systematic increase between 2 and $7 \mathrm{~mm}$ eccentricity. Furthermore, as Figure 10D shows, rod bipolar cell density exceeds ganglion cell density for eccentricities greater than $3 \mathrm{~mm}$, so there must be further spatial pooling of rod signals before they reach the ganglion cells, at least for these eccentricities.

\section{References}

Berrebi AS, Oberdick J, Sangameswaran L, Christakos S, Morgan JI, Mugnaini E (1990) Cerebellar Purkinje cell markers are expressed in retinal bipolar neurons. Soc Neurosci Abstr 16:1075.

Boycott BB, Dowling JE (1969) Organization of the primate retina: light microscopy. Philos Trans R Soc Lond [Biol] 255:109-184.

Boycott BB, Kolb H (1973) The horizontal cells of the rhesus monkey retina. J Comp Neurol 148:115-140.

Boycott BB, Hopkins JM, Sperling HG (1987) Cone connections of the horizontal cells of the rhesus monkey's retina. Proc R Soc Lond [Biol] 203:229-245.

Chun MH, Wässle H (1989) GABA-like immunoreactivity in the cat retina: electron microscopy. J Comp Neurol 279:55-67.

Cicerone CM, Hayhoe MM (1990) The size of the pool for bleaching adaptation in human rod vision. Vision Res 30:693-697.

Curcio CA, Sloan KR Jr, Meyer D (1989) Computer method for 
sampling, reconstruction, display and analysis of retinal whole mounts. Vision Res 19:529-540.

Dacheux RF, Raviola E (1986) The rod pathway in the rabbit retina: a depolarizing bipolar and amacrine cell. J Neurosci 6:331-345.

Daw NW, Jensen JR, Brunken WJ (1990) Rod pathways in mammalian retinae. Trends Neurosci 13:110-115.

Dowling JE, Boycott BB (1966) Organization of the primate retina: electron microscopy. Proc R Soc Lond [Biol] 166:80-111.

Famiglietti EV, Kolb H (1975) A bistratified amacrine cell and synaptic circuitry in the inner plexiform layer of the retina. Brain Res 84:293-300.

Freed MA, Sterling P (1988) The ON-alpha ganglion cell of the cat retina and its presynaptic cell types. J Neurosci 8:2303-2320.

Freed MA, Nakamura Y, Sterling P (1983) Four types of amacrine in the cat retina that accumulate GABA. J Comp Neurol 219:295-304.

Freed MA, Smith RG, Sterling P (1987) Rod bipolar array in the cat retina: pattern of input from rods and GABA-accumulating amacrine cells. J Comp Neurol 266:445-455.

Greferath U, Grünert U, Wässle H (1990) Rod bipolar cells in the mammalian retina show protein kinase C-like immunoreactivity. J Comp Neurol 301:433-442.

Grünert U, Martin PR (1990) Rod bipolar cells in the macaque monkey retina: light and electron microscopy. Invest Ophthalmol Vis Sci 31: ARVO Abstract 2634.

Grünert U, Wässle H (1990) GABA-like immunoreactivity in the macaque monkey retina: a light and electron microscopic study. $\mathrm{J}$ Comp Neurol 297:509-524.

Halasz P, Martin PR (1984) A microcomputer based system for semiautomatic analysis of histological sections. Proc R Microscop Soc 19: 312.

Hendrickson AE, Koontz M, Pourcho RG, Sarthy PV, Goebel DJ (1988) Localization of glycine-containing neurons in the Macaca monkey retina. J Comp Neurol 273:473-487.

Hsu SM, Raine L, Fanger H (1981) Use of avidin-biotin peroxidase complex $(\mathrm{ABC})$ in immunoperoxidase techniques. J Histochem $\mathrm{Cy}-$ tochem 29:577-580.

Kolb H (1970) Organization of the outer plexiform layer of the primate retina: electron microscopy of Golgi-impregnated cells. Philos Trans R Soc Lond [Biol] 258:261-283.

Kolb H (1977) The organization of the outer plexiform layer in the retina of the cat: electron microscopic observations. J Neurocytol 6: $131-153$

Kolb H (1979) The inner plexiform layer in the retina of the cat: electron microscopic observations. J Neurocytol 8:295-329.

Kolb H, Famiglietti EV (1974) Rod and conc pathways in the inner plexiform layer of cat retina. Science 186:47-49.

Kolb H, Nelson R (1983) Rod pathways in the retina of the cat. Vision Res 23:301-312.

Koontz MA, Hendrickson AE (1987) Stratified distribution of synapses in the inner plexiform layer of primate retina. J Comp Neurol 263:581-592.

Koontz MA, Hendrickson AE (1990) Distribution of GABA-immunoreactive amacrine cell synapses in the inner plexiform layer of macaque monkey retina. Visual Neurosci 5:17-28.

Linberg KA, Fisher SK (1988) Ultrastructural evidence that horizontal cell axon terminals are presynaptic in the human retina. J Comp Neurol 268:281-297.

Marc RE, Liu WLS (1985) [ ${ }^{3} \mathrm{H}$ ]glycine-accumulating neurons of the human retina. J Comp Neurol 232:241-260.

McGuire BA, Stevens JK, Sterling P (1984) Microcircuitry of bipolar cells in the cat retina. J Neurosci 4:2920-2938.

Missotten L, Appelmans M, Michiels J (1963) L'ultra-structure des synapses des cellules visuelles de la rétine humaine. Bull Mém Soc Franc Ophtal 76:59-82.

Mori K, Fujita SC, Imamura K, Obata K (1985) Immunohistochemical study of subclasses of olfactory nerve fibers and their projections to the olfactory bulb in the rabbit. J Comp Neurol 242:214-229.

Müller B, Peichl L (1991) Rod bipolar cells in the cone-dominated retina of the tree shrew, Tupaia belangeri. Visual Neurosci, in press.

Müller F, Wässle H, Voigt T (1988) Pharmacological modulation of the rod pathway in the cat retina. J Neurophysiol 59:1657-1672.

Negishi K, Kato S, Teranishi T (1988) Dopamine cells and rod bipolar cells contain protein kinase C-like immunoreactivity in some vertebrate retinas. Neurosci Lett 94:247-252.
Nelson R (1977) Cat cones have rod input: a comparison of the response properties of cones and horizontal cell bodies in the retina of the cat. J Comp Neurol 172:109-135.

Nelson R (1982) AII amacrine cells quicken time course of rod signals in the cat retina. $\mathrm{J}$ Neurophysiol 47:928-947.

Nelson R, Kolb H (1983) Synaptic patterms and response properties of bipolar and ganglion cells in the cat retina. Vision Res 23:11831195.

Nelson R, Kolb H (1985) A17: a broad-field amacrine cell in the rod system of the cat retina. J Neurophysiol 54:592-614.

Oberdick J, Levinthal F, Levinthal C (1988) A Purkinje cell differentiation marker shows a partial DNA sequence homology to the cellular sis/PDGF2 gene. Neuron 1:367-376.

Oberdick J, Smeyne RJ, Mann JR, Zackson S, Morgan JI (1990) A promoter that drives transgene expression in cerebellar Purkinje and retinal bipolar neurons. Science 248:223-226.

Onoda N (1988) A monoclonal antibody specific for a subpopulation of retinal bipolar cells in vertebrates. Neurosci Res [Suppl] 8:113125.

Onoda N, Fujita SC (1987) A monoclonal antibody specific for a subpopulation of retinal bipolar cells in the frog and other vertebrates. Brain Res 416:359-363.

Packer O, Hendrickson AE, Curcio CA (1989) Photoreceptor topography of the retina in the adult pigtail macaque (Macaca nemestrina). J Comp Neurol 288:165-183.

Polyak SL (1941) The retina. Chicago: University of Chicago.

Pourcho RG, Goebel DJ (1983) Neuronal subpopulations in cat retina which accumulate the GABA agonist, $\left({ }^{3} \mathrm{H}\right)$ muscimol: a combined Golgi and autoradiographic study. J Comp Neurol 219:25-35.

Pourcho RG, Goebel DJ (1985) A combined Golgi and autoradiographic study of $\left({ }^{3} \mathrm{H}\right)$ glycine-accumulating amacrine cells in the cat retina. J Comp Neurol 233:473-480.

Pourcho RG, Goebel DJ (1987) A combined Golgi and autoradiographic sludy of ${ }^{3} \mathrm{H}$-glycine-accumulating cone bipolar cells in the cat retina. J Neurosci 7:1178-1188.

Ramón y Cajal R (1893) La rétine des vertébrés. Cellule 9:121-225.

Kaviola E, Dacheux RG (1987) Excitatory dyad synapse in rabbit retina. Proc Natl Acad Sci USA 84:7324-7328.

Raviola E, Gilula NB (1973) Gap junctions between photoreceptor cells in the vertebrate retina. Proc Natl Acad Sci USA 70:1677-1681.

Raviola G, Raviola E (1967) Light and electron microscopic observations on the inner plexiform layer of the rabbit retina. Am $J$ Anat $120: 403-426$.

Rose RD, Rohrlich D (1988) Counting sectioned cells via mathematical reconstruction. J Comp Neurol 272:617.

Sandell JH, Masland RH, Raviola E, Dacheux RF (1989) Connections of indoleamine-accumulating cells in the rabbit retina. J Comp Neurol 283:303-313.

Smith RG, Freed MA, Sterling P (1986) Microcircuitry of the darkadapted cat retina: functional architecture of the rod-cone network. J Neurosci 6:3505-3517.

Steinberg RH, Reid RH, Lacy PL (1973) The distribution of rods and cones in the retina of the cat. J Comp Neurol 148:229-248.

Sterio DC (1984) Estimating number, mean sizes and variations in size of particles in 3-d specimens using disectors. J Microsc 134:127136.

Sterling P, Freed MA, Smith RG (1988) Architecture of rod and cone circuits to the On-beta ganglion cell. J Neurosci 8:623-642.

Strcttoi E, Dachcux RF, Raviola E (1990) Synaptic conncctions of rod bipolar cells in the inner plexiform layer of the rabbit retina. J Comp Neurol 295:449-466.

Vaney DI (1990) The mosaic of amacrine cells in the mammalian retina. Prog Retinol Res 9:49-100.

Wässle H, Riemann HJ (1978) The mosaic of nerve cells in the mammalian retina. Proc R Soc Lond [Biol] 200:441-461.

Wässle H, Yamashita M, Greferath U, Grünert U, Müller F (1991) The rod bipolar cell of the mammalian retina. Visual Neurosci, in press.

Wikler KC, Williams RW, Rakic P (1990) Photoreceptor mosaic: number and distribution of rods and cones in the rhesus monkey retina. J Comp Neurol 297:499-508.

Young HM, Vaney DI (1990) The retinae of Prototherian mammals possess neuronal types that are characteristic of non-mammalian retinae. Visual Neurosci 5:61-66. 